University of Rhode Island

DigitalCommons@URI

Open Access Master's Theses

2020

STEALTH SANCTUARY: THE CHALLENGE OF PROTECTION AT STELLWAGEN BANK NATIONAL MARINE SANCTUARY

Clea Harrelson

University of Rhode Island, cleaharrelson@gmail.com

Follow this and additional works at: https://digitalcommons.uri.edu/theses

Recommended Citation

Harrelson, Clea, "STEALTH SANCTUARY: THE CHALLENGE OF PROTECTION AT STELLWAGEN BANK NATIONAL MARINE SANCTUARY" (2020). Open Access Master's Theses. Paper 1834.

https://digitalcommons.uri.edu/theses/1834

This Thesis is brought to you for free and open access by DigitalCommons@URI. It has been accepted for inclusion in Open Access Master's Theses by an authorized administrator of DigitalCommons@URI. For more information, please contact digitalcommons-group@uri.edu. 


\title{
STEALTH SANCTUARY: THE CHALLENGE OF PROTECTION AT STELLWAGEN BANK NATIONAL MARINE SANCTUARY \\ BY \\ CLEA HARRELSON
}

\begin{abstract}
A DISSERTATION SUBMITTED IN PARTIAL FULFILLMENT OF THE REQUIREMENTS FOR THE DEGREE OF

MASTER OF THE ARTS

IN

MARINE AFFAIRS
\end{abstract}

UNIVERSITY OF RHODE ISLAND

2020 
MASTER OF ARTS IN MARINE AFFAIRS THESIS

OF

CLEA HARRELSON

APPROVED:

Thesis Committee:

Major Professor $\quad$ Amelia Moore
Tracey Dalton
Rod Mather
Nasser H. Zawia
DEAN OF THE GRADUATE SCHOOL

UNIVERSITY OF RHODE ISLAND

2020 


\begin{abstract}
Centuries of exploitation in marine areas have negatively impacted the biomass, diversity, and function of marine habitats and life on a global scale. Marine protected areas (MPAs) are increasingly relied upon as a conservation strategy to address the degradation of marine resources in the U.S., but research on the social context that shapes protection of these marine spaces remains sparse. This study explores protection through the evolution of the people and groups who use the marine resources within MPAs and those who manage MPAs over time. Stellwagen Bank National Marine Sanctuary (SBNMS) is used as a case study to understand how roles and relationships among these may or may not influence MPA management decisions and policy. Data was collected through thirteen semi-structured interviews conducted in the summer and fall of 2019 with individuals who have historic and/or current ties to the use and management of SBNMS, participant observation as a SBNMS intern during the summer of 2019, and document analysis of the management plan and relevant legislation. Finding indicate that SBNMS is faced with multiple challenges related to the federal legislation that governs sanctuaries, dominant regional histories of resource use, and intra-institutional communication in its efforts to enact long-term protection for Stellwagen Bank. Additionally, this site provides valuable insights into how people involved with management at Stellwagen perceive protection of marine space and offers opportunities to reconceptualize protection as a multi-faceted endeavor that includes non-ecological elements such as education and outreach. Results from this research have tangible applications for SBNMS but may also serve as a starting point to evaluate protection definitions and priorities for other regional MPA institutions.
\end{abstract}




\section{ACKNOWLEDGEMENTS}

Throughout this project, faculty and staff in the Department of Marine Affairs have provided consistent guidance and patience as I have worked to complete this project, and generally figure out my life. In particular, thank you to Dr. Amelia Moore for her kindness, even keeled approach to mentorship, and knack for leadership that inspires self-reflection as opposed to reliance on others for answers. We are lucky to have her in our department and in our communities. Thank you to Dr. Tracey Dalton for her unflagging support in helping me hone my research goals and products. I could not have completed this project without her discerning questions and her gracious efforts to connect me with people at the Sanctuary. Thank you to my committee members, Dr. Rod Mather and Dr. Nancy Karraker, for their time and thoughtful comments. Thanks to the roommates and friends who have calmed my nerves over the past semesters and helped round out my grad school life with baked goods, cubicle chats, sea shanties, and Ocean State adventures. A huge thank you to the people who gave their time and energy to part of this project whether through an interview or other conversation. Their willingness to share is everything. Thank you to Sanctuary staff, especially Ben Haskell and AnneMarie Runfola, who lead the way with passion in everything they do and whose help and encouragement were essential to the completion of my research. Thank you to my family who help me stay grounded and keep my sass in check. Finally, thank you to the many scholars who have helped pave the way in thinking about people and the ocean. Without their critically important work to understand and protect the ocean, there would be no thinking to be re-thought (Adams and Mulligan 2003). All shortcomings of this work are my own. 


\section{TABLE OF CONTENTS}



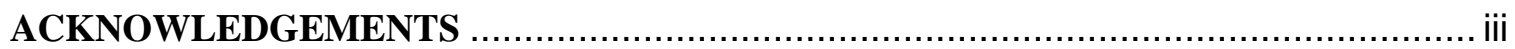

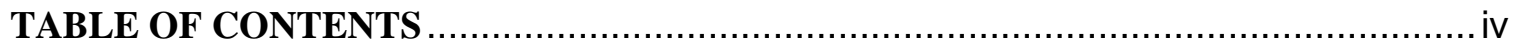

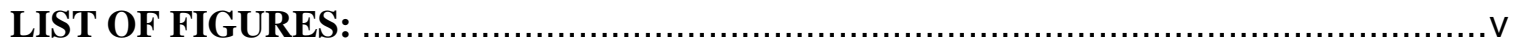

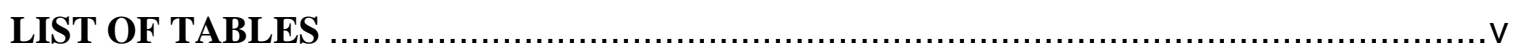

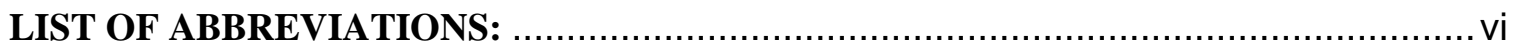

INTRODUCTION: The Evolution of Protection Through MPAs ............................... 1

MPA Definitions and Development ...................................................................... 4

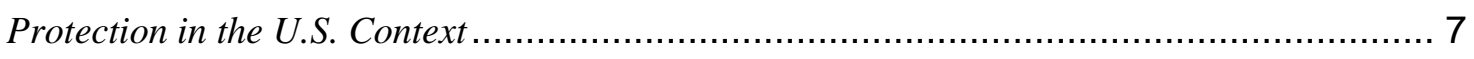

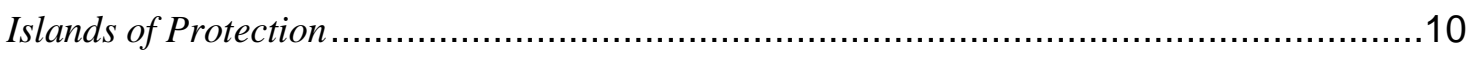

Stellwagen Bank National Marine Sanctuary ………................................................12

Research Justification and Methods:................................................................17

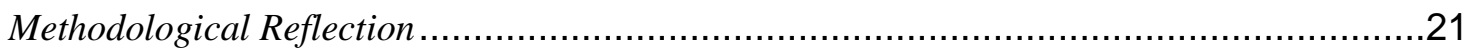

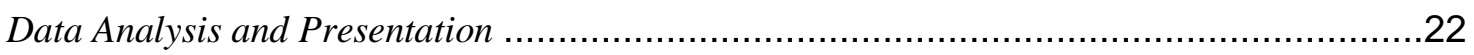

CHAPTER 1: Middle Bank and the Stealth Sanctuary ...........................................23

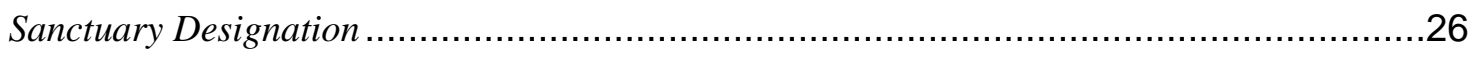

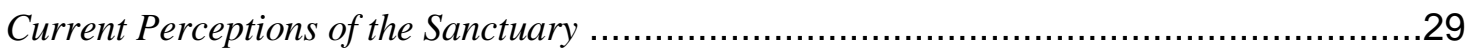

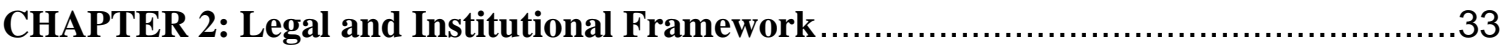

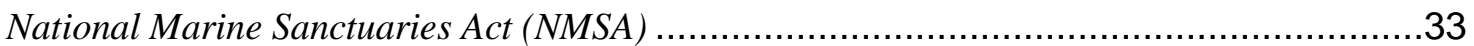

CHAPTER 3: Statues by the Sea and the Legacy of New England Fishing .......................39

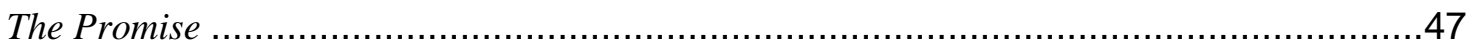

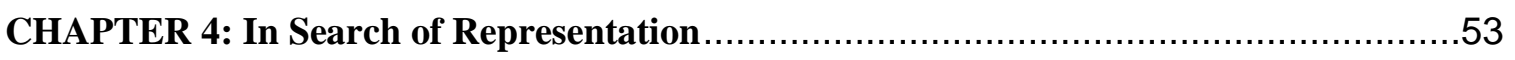

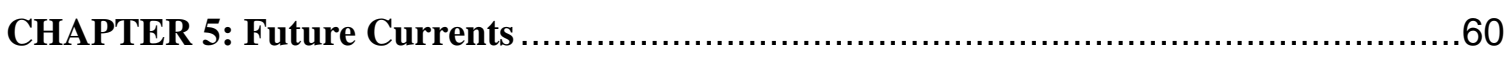

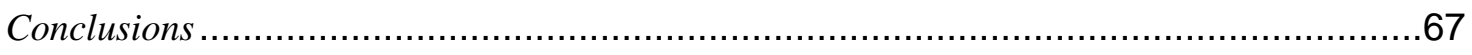

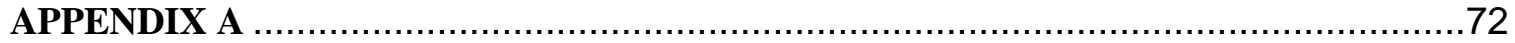

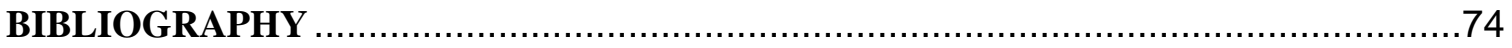




\section{LIST OF FIGURES:}

FIGURE

PAGE

Figure 1 View of recreational boaters on a clear day on Stellwagen Bank June 2019. Photo by

Clea Harrelson. 1

Figure 2. Taken from Gibson et al. 2010. 1734 nautical chart of Massachusetts Bay showing Inner, Middle, and Outers Banks (now referred to as Stellwagen Bank).

Figure 3. Image shows plans for the Arabian Nights Artificial Island and Casino. Taken from PowerPoint by Assistant Professor Susan Farady of the University of New England. .... 27

Figure 4. Figure. This figure was taken from the Sanctuary's 2010 Final Management Plan and Environmental Assessment (ONMS 2010, pg. 217, Figure 127). It shows an example flow of decisions related to an activity in the Sanctuary.

Figure 5. (left) Gloucester Fisherman's Memorial, (right) Gloucester boardwalk) July 2019.

Photos by Clea Harrelson

Figure 6. Sunrise on waters just off the shore of Gloucester, MA July 2019. Photo by Clea

Harrelson. .51

Figure 7. Shadows of whale watch tour passengers on Stellwagen Bank July 2019. Photo by Clea

Harrelson 65

\section{LIST OF TABLES}

\section{TABLE}

PAGE

Table 1. This table summarizes IUCN protected area category descriptions (Dudley 2008)......... 6 


\section{LIST OF ABBREVIATIONS:}

\begin{tabular}{|c|c|}
\hline Abbreviations & Explanation \\
\hline GARFO & Greater Atlantic Regional Fisheries Office \\
\hline IUCN & International Union for Conservation of Nature \\
\hline MAFMC & Mid-Atlantic Fishery Management Council \\
\hline MSA & Magnuson Stevens Act \\
\hline MPA & Marine protected area \\
\hline NEFMC & New England Fishery Management Council \\
\hline NMS & National marine sanctuaries \\
\hline NMSA & National Marine Sanctuaries Act \\
\hline NOAA & National Oceanic and Atmospheric Administration \\
\hline ONMS & Office of National Marine Sanctuaries \\
\hline SAC & Sanctuary Advisory Council \\
\hline SBNMS & Stellwagen Bank National Marine Sanctuary \\
\hline UNCLOS & United Nations Convention on the Law of the Sea \\
\hline
\end{tabular}




\section{INTRODUCTION: The Evolution of Protection Through MPAs}

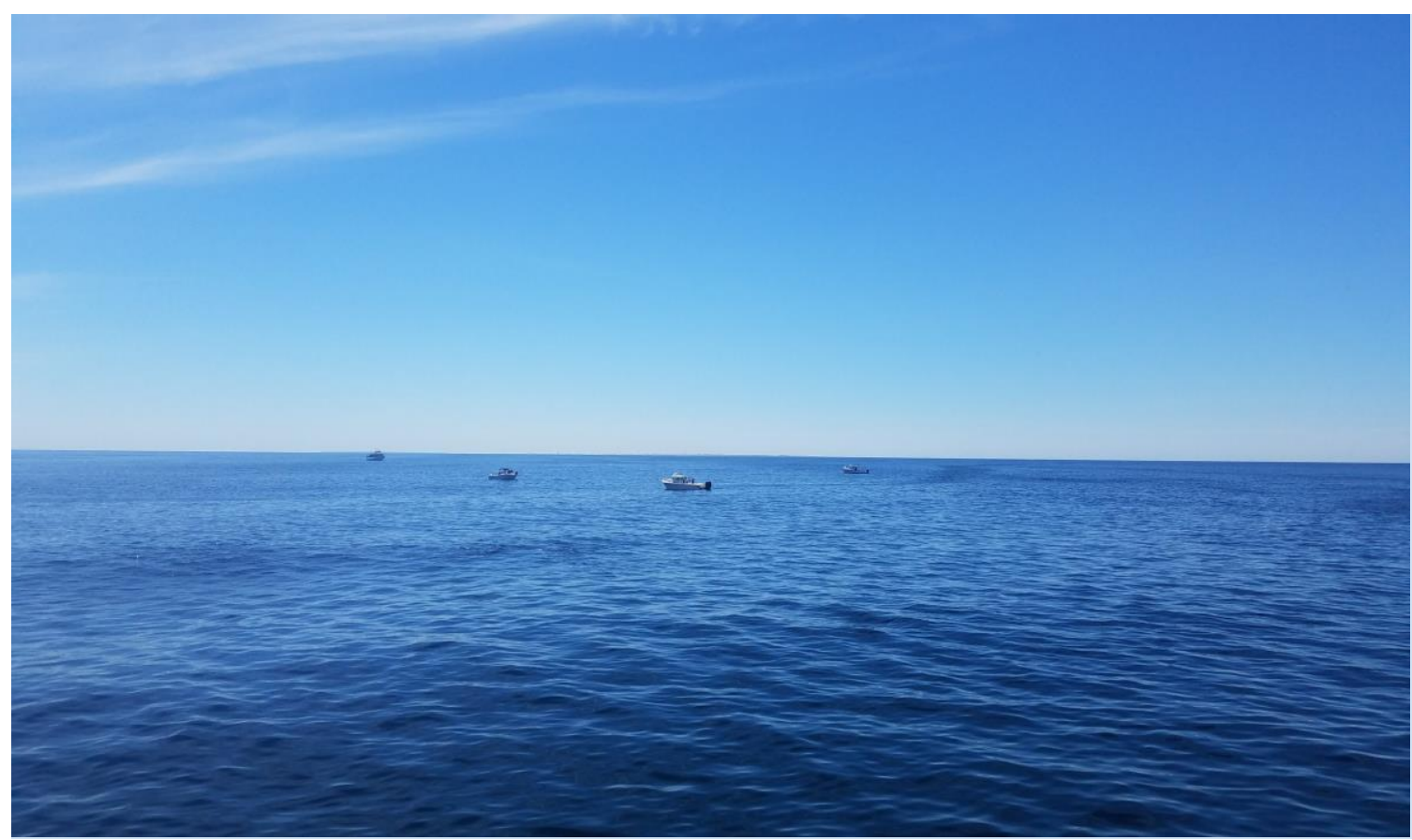

Figure 1 View of recreational boaters on a clear day on Stellwagen Bank June 2019. Photo by Clea Harrelson.

People on the top deck of the boat eagerly pressed against the railing, jostling for camera position, eyes continuously scanning the horizon in search of a small disruption in the deep blue surface of the Atlantic that could signify a whale. Only minutes ago the naturalist on board had announced our arrival at Stellwagen Bank, officially known as Stellwagen Bank National Marine Sanctuary (Sanctuary or SBNMS). This area is wellknown as a seasonal feeding ground for humpback whales. We did not have to wait long before a small group of humpbacks came up for a breath nearby, the white on their pectoral fins glowing green in the phytoplankton rich waters. As our boat slowly turned to move alongside the group, mimicking the whales' direction and pace, a small speed boat, perhaps people on a day trip from Provincetown, began approaching the whales head on. As we watched the boat get steadily closer, the naturalist from our boat called 
out over the speaker system to the other captain. They calmly asked the boat to reduce their speed and approach from the side. After a few repeated warnings, the naturalist's tone became more urgent and angry, and their voice reverberated out across the water. Soon multiple tourists from our boat began shouting at the smaller vessel to turn around, with one person even holding up two middle fingers. Within moments the tone of the tour had transformed from sheer awe at the first sight of whales to defensive towards those who might harm them.

The small boat ultimately stopped before doing any immediate harm and reversed course to the recommended distance of $100+\mathrm{ft}$. (Whale SENSE 2020), but the tension of this moment sparked a larger conversation aboard the whale watch tour where I was doing passenger surveys for the day. As we left that group of whales and people shuffled back to their seats, someone asked about the rules protecting whales in the Sanctuary. The naturalist quickly launched into an explanation of the Whale SENSE program that outlines voluntary guidelines and the Marine Mammal Protection Act. Someone in the front row followed up by asking, "But if it's a Sanctuary, why is there a fishing boat over there?" Upon learning that the Sanctuary itself does not administer rules about fishing, this person said, "Well then what does it protect?"

This question echoed across my experiences conducting research and working as an intern at SBNMS's main office in Scituate, MA. Beyond SBNMS, this initial experience on the whale watch boat fueled a range of complementary questions about MPAs in general. How strictly should an area be protected? For whom and/or what is an area being preserved? How can MPA sites balance both immediate and long-term goals for protection? These broad questions have become critical in shaping my approach to 
this project and understanding what SBNMS is now and what it could be in the future. Confusion about the scope of the Sanctuary's protection, and perhaps more importantly, what constitutes protection, represents the core dissonance in how the relevance of the SBNMS is perceived both internally among those involved in Sanctuary management and people who use the marine space within the Sanctuary's boundaries. Through this project, I explore the contested meaning of protection at SBNMS by examining the roles and relationships among sanctuary managers and people who use resources in SBNMS over time. By tracing the evolution of different groups and individuals I was able to make preliminary assessments about how those roles and relationships impact management decisions. I situate this line of questioning in an ever-expanding realm of literature that categorizes and evaluates ocean protection and marine protected areas (MPAs).

The term MPA is used frequently in discussions about tools for marine conservation, but there is no singular definition of an MPA or the purpose of an MPA (Agardy et al. 2003, Baur et al. 2013, Sala et al. 2018). Discourse around what qualifies as an MPA and the normative goals of MPAs are often dominated by ecological factors despite a growing body of research that suggests critical links between social success and the sustainability and effectiveness of MPA projects (Christie 2004, Dalton 2005, Morin 2001, Pomeroy et al. 2007, Singleton 2009, Wahle et al. 2003). Because of the multiplicity of understandings about MPA definitions and objectives, exploring the histories of SBNMS and the social context of the Sanctuary's management will help illuminate current challenges and opportunities for managers and people who use this Sanctuary space. 


\section{MPA Definitions and Development}

Increasing demand for marine resources often results in not only overexploitation but also opportunities for escalation of conflict over how uses are prioritized in marine spaces (Inniss et al. 2017, Jackson et al. 2001). While marine management strategies have historically been enacted through sectoral regulation, the development of the United Nations Convention on the Law of the Sea (UNCLOS) and the passage of the Magnuson Stevens Act in the late 1970s marked the beginning of a slow shift towards coordinated, multi-sectoral management designed to mitigate the diverse demands on marine resources (Cowan et al. 2012). There are many methods that seek to manage resources through the regulation of marine space, but MPAs are often discussed as key conservation frameworks to aid in the development of multi-sectoral management (Caveen et al. 2014, Mahajan and Daw 2016). MPAs are also increasingly viewed as a means of climate change adaptation and economic development (Fox et al. 2012).

Definitions of what constitutes an MPA vary widely depending on context (Baur et al. 2013, Caveen et al. 2014, Dudley 2008), with some authors even arguing that the lack of a precise definition is detrimental to coordinated conservation efforts (Costello and Ballantine 2015). Despite this, MPAs can be generally understood as a form of spatial management that regulates human behavior within a designated marine zone through a series of rules. Much like terrestrial protected areas, MPAs may completely or partially exclude access for certain activities through a mixture of no-take (no extractive uses) and/or multi-use zoning. The actual level of protection for marine resources ranges from marine reserves, a specific subset of MPAs that prohibit all forms of extractive use, to multi-use zones with only minimal protection against dumping or extractive use 
(Baur et al. 2013, Caveen et al. 2014, NCEAS 2001). MPAs may also be created with specific goals in mind such as protection of an important marine feature or preservation of cultural heritage through artifacts, sites, or activity.

The U.S. currently defines an MPA as "any area of the marine environment that has been reserved by Federal, State, territorial, tribal, or local laws or regulations to provide lasting protection for part or all of the natural or cultural resources therein" (US Executive Order 13158 2000). According to the International Union for Conservation of Nature (IUCN), a protected area is, “A clearly defined geographical space, recognised, dedicated and managed, through legal or other effective means, to achieve the long-term conservation of nature with associated ecosystem services and cultural values" (IUCN 2020). While these statements have some overlap, the international definition specifically mentions management and prioritizes conservation of nature with cultural values as secondary.

Both definitions emphasize the need for lasting, or long-term, protection of resources. The IUCN additionally created six categories for protected areas (both terrestrial and marine) to facilitate communication across varying countries, agencies, and institutions (Table 1) (Dudley 2008). While both the U.S. and the IUCN acknowledge the context dependent nature of MPA development, these definitions are frequently used as reference points for understanding what qualifies as an MPA. 
Table 1. This table summarizes IUCN protected area category descriptions (Dudley 2008).

\begin{tabular}{|c|c|}
\hline Protected Area Category & Description \\
\hline Ia. Strict Nature Reserve & $\begin{array}{l}\text { Area set aside to protect biodiversity and/or other important } \\
\text { geological features with strict limitations for human access. } \\
\text { May serve as biological reference areas. }\end{array}$ \\
\hline Ib. Wilderness Area & $\begin{array}{l}\text { Strongly protected areas with limited human modification. } \\
\text { Intended to represent and preserve an area in its natural } \\
\text { condition. }\end{array}$ \\
\hline II. National Park & $\begin{array}{l}\text { Areas designed to protect large-scale landscapes and natural } \\
\text { processes with carefully managed vistorship. }\end{array}$ \\
\hline III. Natural Monument & $\begin{array}{l}\text { Areas created to protect a specific natural feature such as a } \\
\text { cave, sea mount, or even a historic grove of trees. These areas } \\
\text { are typically smaller as they are tied to a feature rather than } \\
\text { landscape. }\end{array}$ \\
\hline $\begin{array}{l}\text { IV. Habitat/ Species } \\
\text { Management }\end{array}$ & $\begin{array}{l}\text { Areas set aside to protect important species and/or their } \\
\text { habitat. Research and other management activities may take } \\
\text { place, as needed. }\end{array}$ \\
\hline $\begin{array}{l}\text { V. Protected Landscape/ } \\
\text { Seascape }\end{array}$ & $\begin{array}{l}\text { Areas designed to safeguard valuable human and nature } \\
\text { interactions that have developed over time tied to particular } \\
\text { spaces on land or sea. Applies to areas that have historic } \\
\text { long-term human use. }\end{array}$ \\
\hline $\begin{array}{l}\text { VI. Protected Area with } \\
\text { Sustainable Use of Natural } \\
\text { Resources }\end{array}$ & $\begin{array}{l}\text { Areas designated to protect natural landscapes/seascapes and } \\
\text { sustainable resource use or low-level non-industrial resource } \\
\text { use. }\end{array}$ \\
\hline
\end{tabular}


Overfishing and the prevention of overfishing has been a driving force in MPA development, and MPAs are commonly portrayed as an alternative to the perceived failures of conventional fisheries management techniques (Baur et al. 2013, Bohnsack et al. 2004, Caveen et al. 2014, Guénette et al. 1998, Murawski et al. 2005, Pomeroy et al. 2007). MPA projects also represent efforts to shift conservation policy away from species-specific measures towards an ecosystem level approach (Dell'Apa et al. 2015, Douvere 2008, Halpern et al. 2010). While conventional management strategies such as closed seasons, catch limits, gear restrictions, and effort limits have the potential to protect habitat, non-target species, and non-ecological values, MPAs, in theory, make these protections more explicit and consistent. By managing a space holistically, species, structures, and interactions that are not directly emphasized in a management plan can also receive the benefits of that management plan through overlap in location (Caveen et al. 2014, Gell and Roberts 2003, Inniss et al. 2017, Sala and Giakoumi 2018). In addition to indirect benefits for non-target resources, MPAs can also be framed as opportunities to reduce costs in administration and enforcement that can occur in single-species management plans (Berghöfer et al. 2008, Johannes 1998, Halpern et al. 2010).

\section{Protection in the U.S. Context}

MPAs are not a new form of marine resource management. For instance, authors such as Johannes (1978) argue that nearly every method employed by modern fisheries managers, including closed areas (MPAs), has been in use for hundreds of years, if not longer, in some form by fishers in the tropical Pacific Ocean. However, in the (settler colonial) U.S., MPAs such as scientific research reserves have been sporadically established since the 1920s, although they first received major attention by academic 
researchers and policy-makers in the U.S. as the result of Beverton and Holt's 1957 paper on fish population dynamics (Beverton and Holt 1957, Guénette et al.1998, National Research Council 2001). In contrast to this more recent MPA movement that began in the mid to late 1900 s, spatial management efforts in the late 1800 s and early 1900s were often seasonal and/or rarely included full fishing restrictions (Bohnsack et al. 2004).

The U.S.'s current interest in more permanent forms of marine spatial management can be traced back to 1966 and the establishment of the Commission on Marine Science, Engineering and Resources, or the Stratton Commission. The Commission, fueled by both a budding academic interest and a political desire to prepare and respond to political changes of the era, produced a final report in 1969, "Our Nation and the Sea: A Plan for National Action," that called for concrete congressional action (Scheiber 1998). This report, along with high profile environmental catastrophes such as the 1967 grounding of the Torrey Canyon and a major oil spill off of the coast of California in 1969 helped spur a number of domestic environmental laws in the early 1970s (Chandler 2006, Scheiber 1998).

The national marine sanctuary system was created in 1972 with the passage of the Marine Protection, Research, and Sanctuaries Act of 1972 (now the National Marine Sanctuaries Act, NMSA), a law strongly focused on the prevention of dumping and industrial development (Chandler 2006). Although there are other forms of MPAs within U.S. waters, the national marine sanctuary (NMS) system is one of the most prominent attempts to protect "nationally significant areas in the ocean and Great Lakes" from degradation (Sarri 2018). The NMSA has been reauthorized six times since its initial 
creation with the most recent reauthorization occuring in 2000 (NOAA 2020). Of the ocean within the U.S. Exclusive Economic Zone, approximately $0.5 \%$ is protected through the NMS system, although the level and effectiveness of protection are contested (Borrelli 2009).

There are a total of fourteen sanctuaries and two national monuments managed by the Office of National Marine Sanctuaries (ONMS) under the umbrella of the National Oceanic and Atmospheric Administration (NOAA). This office, in turn delegates management of a sanctuary to the sanctuary staff who receive non-binding recommendations from the Sanctuary Advisory Council (SAC). The sanctuary staff, with guidance from the SAC, are tasked with comprehensively managing a given space for the long-term protection of natural and cultural resources, promoting public awareness of issues in the marine environment, and working "to facilitate to the extent compatible with the primary objective of resource protection, all public and private uses of the resources of these marine areas not prohibited pursuant to other authorities" (NMSA 2000). Each individual sanctuary is additionally expected to facilitate cooperative research and create policies responsive to new research (ONMS 2010).

Although management of marine spaces that balances the needs of many groups is generally compatible with the goals of other MPA projects nationally and internationally, the framing and implementation of the NMSA is a source of frequent debate in U.S. MPA literature (Borelli 2009, Brax 2002, Chandler and Gillelan 2007, Owen 2002). While there are some hopeful perspectives on the NMSA, such as Baur et al. 2013, who argues that the NMSA is unique, and thus powerful, in its mandate for place-based rather than sectoral management, the NMSA is generally viewed as underdeveloped in 
application and chronically underfunded (Owen 2002, Reeves 2000). In particular, the NMSA is criticized for failing to provide the legal clarity of purpose and tools needed to carry out its original goal of meaningful protection of marine resources (Brax 2002, Chandler 2006, Owen 2002, Reeves 2000, Sutherland 2008, Weber 1988, 1997). Despite this, the NMS system is still referenced as the central example of U.S. MPA development (Reeves 2000, De Santo 2013).

Islands of Protection

Controversy regarding the effectiveness of the NMSA is largely related to language and the broader debate around the effectiveness of varying levels of ecological protection. Since the early efforts to create MPAs in the U.S., questions about the legislative boundaries of proposed ocean protections have been prominent. Initial hopes for marine reserves to become spaces similar to national parks and comparisons of the NMSA to the Wilderness Act of 1964 ultimately shifted to support for sustainable, multi-use zones and an Act that was intended for flexible, if at times conflicting uses (Chandler 2006). This national priority of multi-use management mirrors international MPA trends. One study even suggests that $94 \%$ of MPAs allow fishing despite the overarching concerns about protection against overfishing in MPA creation (Costello and Ballantine 2015). While the concept of context dependent MPA development with a range of goals for protection is often acknowledged as a practical reality of conservation work, MPA literature makes a clear distinction between the perceived benefits of MPAs that allow for multiple uses as opposed to those which are partially or completely protected from extractive uses. All forms of MPAs are acknowledged as having some conservation potential, but no-take MPAs or MPAs that are strongly protected are held 
up as ideal forms of marine conservation with the greatest ecological benefits within some segments of the conservation community (Costello and Ballantine 2015, Jones 2014, Lubchenco and Grorud-Colvert 2015, NCEAS 2001, Sala and Giakoumi 2018).

Preference for no-take zones may be influenced by terrestrial conservation principles, but it is also supported by research indicating strong links between strict notake MPAs and increases in biodiversity, abundance, and ecosystem resilience (Lubchenco and Grorud-Colvert 2015). However, the perceived high conservation potential for strongly protected MPAs is marred by the simultaneous recognition that many of the world's MPAs are not achieving their conservation goals as a result of ineffective management and enforcement (Hargreaves-Allen et al. 2011, Jones 2014, Pomeroy et al. 2004). Additionally, many MPA sites have a strong focus on ecological research and monitoring, despite evidence that suggests addressing the social context of MPAs is central to their conservation effectiveness (Pomeroy et al. 2007, Wahle et al. 2003). Challenges in MPA management are not homogenous but themes of understaffing, underfunding, lack of high quality assessment, inability to address issues external to the MPA, and conflict with people who live, work, and play in the area of resource protection are common (Agardy et al. 2011, Gill et al. 2017, Hargreaves-Allen et al. 2011, Jones 2014, Lubchenco and Grorud-Colvert 2015).

Beyond surface level management efforts to protect marine resources, MPAs are rooted in a particular set of beliefs that shape how we view threats to the ocean, as well as solutions. Some authors such as Bohnsack (2004) frame protection of ecosystems and human exclusion in some areas as a duty, implying that because we have the power to so dramatically alter the seascape, we must also take up the responsibility of protecting it. 
Others such as Roberts (2012) and Costello and Ballantine (2015) highlight the rapid decline of many marine species and argue strongly for high levels of spatial protection as an immediate source of relief from concentrated human extraction.

While it is widely acknowledged that the world is undergoing an ecological transition and faces sharp declines in biodiversity, other authors such as Hillborn (2015) and Agardy et al. (2011) call into question the ability of MPAs to address central threats to the ocean such as climate change, ocean acidification, and pollution. In this context, much of the controversy over MPA development and perceived MPA failures is controversy over "protection" and non-biological factors that influence protection. Contested understandings of what is strongly protected and what is not often focus on the presence/absence of on the water restrictions as opposed to the broader range of social structures that enable destructive behavior in the first place. Framed in this way, the problem appears as simple lack of regulation and enforcement, and deeper questions about how cultural values and social beliefs impact our use of marine resources may be left underdeveloped or unexplored entirely. To begin to unpack the ongoing debate in MPA literature about what protection is currently and what it should be, I trace the thread of protection from land to water throughout this text through the lens of SBNMS. For the purposes of this project, I will use the term "protection" to refer to the protection of both natural and cultural resources, unless otherwise specified.

\section{Stellwagen Bank National Marine Sanctuary}

The waters over Stellwagen Bank, Tillies Bank, and the southern portion of Jeffreys Ledge were officially designated as the 12th National Marine Sanctuary in the system through The Oceans Act of 1992 (P.L. 102-587, Sanctuaries and Reserves 
Division 1993). Its full name, the Gerry E. Studds Stellwagen Bank National Marine Sanctuary, pays homage to both Gerry Studds, the Massachusetts Congressman who helped push forward its designation, and Henry Stellwagen, who mapped the bank in 1854-1855 while working for the U.S. Coast Survey (Sanctuaries and Reserves Division 1993). Although the Sanctuary was the first permanent, open-water MPA to be created in the Gulf of Maine, it was not the first protected area in the region to be proposed or implemented. For example, the Massachusetts Ocean Sanctuaries Act of 1970 led to the creation of five sanctuary zones in state waters (Ocean Sanctuaries Act 2011). Earlier proposals for offshore protected areas were also discussed throughout the 1980s and included features such as Deer Island, Maine as well as portions of Stellwagen Bank (Brody 1998).

However, the nomination put forth by the environmental non-profit Defenders of Wildlife, Inc. and Dr. Charles Mayo from the Center for Coastal Studies in 1982 was the first to encompass the entirety of Stellwagen Bank, formerly known as Middle Bank. The site was elevated to Active Candidate Status within the National Marine Sanctuary Program in 1989, and public comments on the draft Environmental Impact Statement and management plan were solicited in spring of 1991 (Brody 1998, Sanctuaries and Reserves Division 1993). By the late 1980s and early 1990s support for the creation of the Sanctuary had grown, and the final designation was pushed through by groups such as the Stellwagen Bank Coalition and the efforts of Senator John Kerry and Representative Gerry Studds (Borelli 2009, Sanctuary Reserves Division 1993). The designation of SBNMS was also strongly supported by some, although not all, groups of commercial 
and recreational fishers interested in protecting important fish habitat from industrial development (Borelli 2009, Speaker 2).

The Sanctuary's institutional structure slowly emerged over the next decade, with the release of the first management plan in 1993 and the creation of the current Sanctuary Advisory Council (SAC) in the fall of 2001 (SBNMS SAC Charter 2018). Within the initial management plan, "long-term protection of the living and non-living resources of the Stellwagen Bank system" is listed as the highest management priority (Sanctuaries and Reserves Division 1993, pg. 77). In support of this goal, the following activities are prohibited in the Sanctuary: discharge and deposit of materials; dredging excavation, and alteration of the seafloor (excluding impacts from tradition fishing operations); incineration of trash; lightering activities; intentional removal, taking or injuring of historical or cultural resources; and the taking any marine mammal, reptile, of seabird (except through commercial fishing operations). Other focus areas to support these core restrictions and help add to knowledge about the resources of Stellwagen Bank include research to establish baseline features and processes of the area, education, and coordination with existing regulatory authorities (Sanctuaries and Reserves Division 1993, pgs. 80-83). In addition, the SBNMS SAC developed a vision statement in 2005 that was adopted into the 2010 management plan:

The Stellwagen Bank National Marine Sanctuary is teeming with a great diversity and abundance of marine life supported by diverse, healthy habitats in clean ocean waters. The ecological integrity of the sanctuary is protected and fully restored for current and future generations. Human uses are diverse and compatible with maintaining natural and cultural resources. (ONMS 2010, pg. 6) 
Since its designation in 1992, the Sanctuary has completed two management plans $(1993,2010)$ and two sanctuary condition reports $(2007,2020)$. The next management plan review process is scheduled to begin in spring of 2020. Additionally, the Sanctuary has been under the leadership of three different superintendents, with the most recent transition occurring in fall of 2018 with the hiring of retired U.S. Coast Guard Captain Peter DeCola.

The sanctuary covers 638 square nautical miles in federal waters, with its western boundary beginning roughly 25 miles east of Boston. The primary marine features in the sanctuary are a series of raised plateaus - Stellwagen Bank, Tillies Bank, and southern sections of Jeffreys Ledge - that provide important habitat for over 575 marine species, including organisms such as flounder and cod (Sanctuaries and Reserves Division 1993, ONMS 2010). Stellwagen Bank is also known for supporting large populations of sand lance, a favorite food of whales. The sanctuary is visited by 17 species of marine mammals, including northern right whales, and serves as a stopover point for multiple other organisms such as Atlantic Puffins and bluefin tuna. Whale watching trips to SBNMS have both a national and international reputation and are estimated to generate over $\$ 30$ million dollars in revenue for the region (Borrelli 2009, Ehler 2011, Hoagland and Meeks 2000, ONMS 2010). Other uses of the sanctuary include recreation and commercial fishing, boating, diving, and bird watching (ONMS 2010).

The rich concentration of marine organisms that result from the anomaly of the Bank's shallow depths have made this space a valuable source of sustenance for thousands of years (Terrell 1994). Archeological evidence suggests ancestors of people such as the Massachusett, Wampanoag, Nauset, Wabanaki, and Agawam, whose 
historical territories bordered the crescent of what is now known as Massachusetts Bay, made use of the plethora of wildlife supported by Stellwagen Bank and surrounding formations long before the arrival of white European settlers (Bernstein 2006, Terrell 1994). Additionally, research indicates that the archeological record for New England coastal communities is fairly continuous, contradicting previous understandings of indigenous lifestyles marked by large scale mobility and agriculture as the dominant pathway to community stability (Bernstein 2006). While there is discussion of early indigenous coastal life through discoveries such as shell middens (piles often consisting of oyster and whelk shells) and the discovery of what was likely a cornfield on Cape Cod in academic literature, research describing the extent of nearshore and offshore travel and fishing around features such as the Stellwagen Bank in any depth is nonexistent (Bernstein 2006, Mrozowski 1994, Terrell 1994).

In addition to biological features of Stellwagen Bank, the Sanctuary is also mandated by the NMSA and the National Historic Preservation Act to "locate, assess, protect, manage, and interpret" maritime heritage resources within its boundaries (GARFO 2018, pg. 2). So far research related to shipwrecks has been the primary focus of the Sanctuary's efforts to locate and document maritime heritage resources, although scholars such as Terrell (1994) argue that evidence of now submerged settlements from early native peoples likely exists. Because of its proximity to several major ports along New England's coast and its importance as a fishing ground, the Sanctuary contains a total of 50 identified shipwrecks and historic reports of approximately 200 wrecks that have yet to be located. Known shipwrecks include passenger vessels, coal and granite carrying schooners, and modern and historic fishing boats, some of which sank as far 
back as the late 1800s (although there were undoubtedly wrecks before this). To date, five shipwrecks have been listed on the National Register of Historic Places (ONMS 2010).

While the Sanctuary does have direct authority to protect shipwrecks and other historic cultural resources through the creation of "historic sites" and "heritage preserves," there are no Sanctuary specific fishing regulations, and the Sanctuary works with the Greater Atlantic Regional Fisheries Office (GARFO) the New England Regional Fishery Management Council (NEFMC) on fishery issues (ONMS 2010, ONMS 2020, Speakers 9 and 13). All fishing regulations and zones, such as the Western Gulf of Maine Closure Area, which covers $22 \%$ of Sanctuary space, are implemented through the GARFO and the NEFMC. Fishing regulations were also specifically excluded from the Sanctuary's designation document, although this does not preclude future changes to encompass more direct input in how fishing activity is managed in the Sanctuary (Sanctuaries and Reserves Division 1993).

\section{Research Justification and Methods:}

Research to assess biological and socioeconomic dimensions of the sanctuary such fish stocks, cultural artifacts, and values associated with whale watch tourism is ongoing at SBNMS (ONMS, 2010, 2020). However, there has been little evaluation of the relationships between groups of people who use SBNMS and sanctuary managers and the impacts that these relationships may have on sanctuary management, a gap that parallels the direction of broader MPA research (Jones 2014, Morin 2001). Sanctuary management in this context refers to the broad range of education, outreach, and research and policy actions that comprise the Sanctuary's short-term and long-term direction. 2020 
marks 28 years since SBNMS was designated, and while there have undoubtedly been many positive developments for the Sanctuary and the level of public awareness about the resources of Stellwagen Bank, the accomplishments of SBNMS are also viewed critically by those who feel the sanctuary has not adequately protected this area from pressures such as commercial fishing (Borrelli 2009, Owen 2002).

Through understanding relationships among those who manage the sanctuary and those who use the sanctuary, this research project will add much needed social context to debates about the goals of the sanctuary. Inquiry into these topics is particularly relevant for SBNMS given the ongoing 2020 management plan review process. To date, there has been limited social science research on how the people and politics of SBNMS impact management processes and decisions at the site. This study centers on three major research questions: a) How have the roles and relationships among sanctuary managers and people who use resources in SBNMS evolved over time? b) How did/do these relationships influence sanctuary management? And c) How does social context shape what constitutes protection in an MPA? In this context, management refers primarily to the process and function of decision-making as opposed to management outcomes or formally written management objectives. These questions, along with related subquestions, will provide critical context for the sanctuary's current situation and will help managers, as well as people who use the sanctuary, understand the impacts of various groups on past and present policy. This research is important for understanding the immediate context of management decisions at the Sanctuary, but it also offers insights that may be helpful as the Sanctuary reevaluates its long-term vision for the future of people and organisms of Stellwagen Bank. 
To begin to answer these questions, I used a suite of qualitative research methods to conduct an exploratory case study of the Sanctuary and its context. Case studies are valuable openings to examine complex phenomena related to a given place or topic. Indepth analysis of a site such as SBNMS enables novel information and connections that might be missed in research taking place on larger scales to be brought forward (Creswell et al. 2003). My research tools included semi-structured interviews, participant observation, and document analysis. This research was primarily based in Scituate, MA but also involved trips to other coastal towns and ports such as Gloucester, MA and Plymouth, MA as needed to include relevant people who are involved in management of the sanctuary or use of the sanctuary space. Data collection occurred from June through September 2019.

\section{Semi-Structured Interviews}

I used semi-structured interviews as opposed to a more structured interview or survey to allow flexibility in both the question format and response. The open-endedness of semi-structured interviews created a more collaborative approach to research and helped ensure that interviewees had space to convey important perceptions about the Sanctuary despite my choice of questions (Luo and Wildemuth 2009). Interviews primarily targeted: sanctuary staff, SAC members, recreational fishers, commercial fishers, and non-fishing recreational users such as recreational boaters, whale watch companies, and divers. Interviewees ranged from people who have been involved with the Sanctuary since designation to those who became involved only in the last few years. Some people had been to one or two SAC meetings whereas others are actively involved in creating and implementing Sanctuary policy. People I spoke with represented interests 
including commercial fishing, recreational fishing, conservation, and NOAA (including SBNMS staff). I used snowball sampling, also known as chain referral, to increase sample size and identify individuals whose role was referenced as important but not clearly defined by a SAC position or title (Bernard 2017).

Over the summer of 2019 I conducted 13 interviews, 12 in person and one over the phone. Interviews ranged in length from 45 minutes to 2.5 hours. Interviewees (referred to as Speakers throughout this document) were broadly asked to describe their relationship with the Sanctuary and respond to a number of open-ended questions about how the Sanctuary has changed over time in terms of actors involved in management and direction of management (Appendix A). Wording and exact questions varied depending on the person's background and their own interests. Typed interview transcripts were sent back to each interviewee who requested it for review and/or correction. This style of analysis seeks to make use of the depth of information provided by open-ended forms of questioning as opposed to limiting the scope of inquiry with a more rigid, positivist approach (Charmaz and Belgrave 2012).

\section{Participant Observation}

Participant observation data collection was facilitated through a part-time internship at the SBNMS main office in Scituate from May 20 - August 1, 2019. Throughout the internship I gained exposure to sanctuary processes such as staff meetings, Sanctuary events, and day to day office life. I made connections and had informal conversations about the Sanctuary with Sanctuary staff, SAC members, commercial fishers, recreational boaters, recreational fishers, whale watching companies, recreational divers, tourists and others who are simply interested in the Sanctuary space. 
In addition, I attended SAC meetings, volunteered for ongoing research projects at the Sanctuary, and participated in Sanctuary events. These experiences were documented through field notes. Participant observation methodology allowed for in situ learning and the collection of data through personal interactions as well as non-verbal communication (Moore 2018). Researchers in other marine spatial management contexts have used similar participant observation methods to inform their work (Gray 2010, Wiener et al. 2009).

Document Analysis

Due to their respective roles as federal institutions, SBNMS and ONMS have left a thorough trail of public documentation. Texts such as management plan reviews, designation documents, public bulletins, and others provided an opportunity to compare and contrast perceived accounts of changes in management with documented accounts of changes in management. This portion of research was used to supplement interviews and participant observation and assess how people's perceptions related to official Sanctuary communications. This methodology is common to case study research and efforts to triangulate qualitative information for added clarity (Bowen 2009).

\section{Methodological Reflection}

The questions and methodologies I use in this project also mean that some notable elements of the Sanctuary's context are left out. Perhaps most importantly, my research was highly focused on understanding this particular site through the lens of existing management structures, and as a result, larger questions about the colonial nature of 
NOAA and scientific paradigms that inform management are not addressed (Smith 2013).

Additionally, by choosing to orient my work towards people who are already involved in Sanctuary management or who are known to Sanctuary managers, I wound up collecting data largely framed by existing hierarchies rather than data that lends itself to questioning the hierarchies of Sanctuary management. This thesis is thus a presentation of the beginnings of a more thorough and critical research project, rather than the final component of such a project.

\section{Data Analysis and Presentation}

Data collected through interviews, participant observation, and document analysis were organized and coded over the course of fall 2019 and winter 2020 (no software was used). Results were explored using practices from grounded theory to draw out recurring themes and to help make clear the mutually constructed perceptions of SBNMS that emerged from fieldwork (Charmaz and Belgrave 2012). This process means that not all information from notes or interviews was used. It allowed me to distinguish focal points of conversation, such as important events, people, and or beliefs, as well as subject areas that were rarely broached or missing from both my own questions and the responses of people involved in this project.

To begin to untangle the layers of people and politics that are tied to this physical space, Chapter 1 of this thesis focuses on what Stellwagen Bank and the Sanctuary have meant to people over time and what they mean to people now. This section provides the necessary context to understand why I asked the questions that led to evidence presented in the remaining sections. Chapter 2 demonstrates the ways in which a regional institution like the Sanctuary is enmeshed in a federal regulatory framework and how the 
weaknesses in this larger system of sanctuaries may impact SBNMS. This section provides the broader foundation from which the legacy of fishing in New England is explored in Chapter 3. Chapter 3 addresses the seemingly impervious legacy of fishing and raises important questions about how historical perspectives of resource use impact current management. Chapter 4 narrows the scope of analysis even further to institutional scale challenges in representation and explores how the Sanctuary's approaches to representation may impact its regional presence. Finally, Chapter 5 addresses how people view the Sanctuary's current direction as it relates to the concept of protection. Collectively, the sections of this text are an initial attempt to contextualize and question the Sanctuary's current management decisions and directions. Through this project I hope to spark continued questioning and reflection about what the institution of SBNMS currently is and what it might become.

\section{CHAPTER 1: Middle Bank and the Stealth Sanctuary}

Stellwagen Bank has been recognized as a fertile fishing ground for thousands of years. Native peoples, such the Massachusett, Wampanoag, Nauset, Wabanaki, and Agawam inhabited, and continue to inhabit, what is now Massachusetts Bay (Native Land Digital 2018). These tribal nations likely had access to the area during the geological period when the bank was above sea level and supported terrestrial vegetation and coastal resources, around 12,000 - 6,000 BP. Glacial melt and rising sea levels gradually reduced access to the area, and by the time white Europeans such as Captain John Smith arrived in the region in the early 1600s (ONMS 2020), Stellwagen Bank, then called Middle Bank or Middle Ground, was fully submerged (Terrell 1994). European 
scouts quickly recognized the abundance of fish and other marine organisms near Stellwagen Bank and used this wealth of resources to encourage colonial settlement (Borrelli 2009, Mather and Jensen 2010). Fishing remains an important use of Stellwagen Bank to this day. Despite the diminished catch relative to historic quantities, combined fisheries resources extracted from the sanctuary between 2007-2016 were valued at over $\$ 194$ million (ONMS 2020, Terrell 1994). This history of use and its position at the mouth of the Massachusetts Bay mean that Stellwagen Bank has been an important feature locally and within the larger Gulf of Maine system for thousands of years (Terrell 1994).

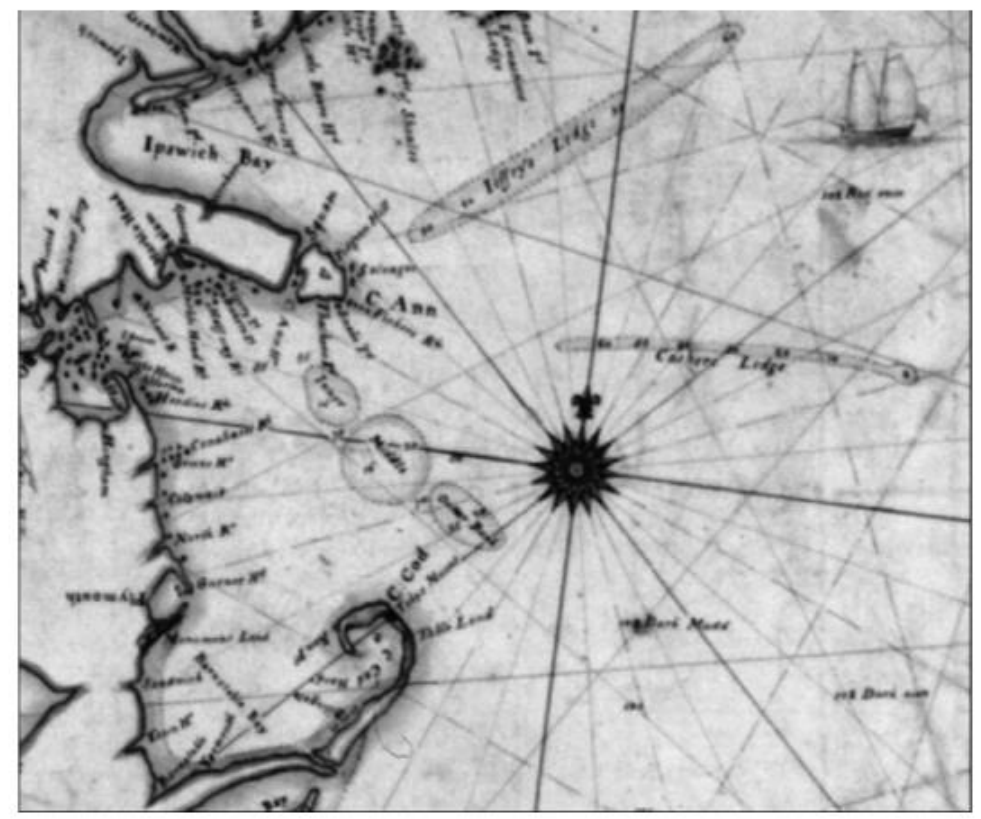

Figure 2. Taken from Gibson et al. 2010. 1734 nautical chart of Massachusetts Bay showing Inner, Middle, and Outers Banks (now referred to as Stellwagen Bank).

Stellwagen Bank's popularity as a fishing ground primarily relates to its natural geological features. The bank itself is an underwater plateau ranging from 65-120 ft. on 
the top to $300-600 \mathrm{ft}$. on the slopes and fissures that rim its edge. The benthic surface of the bank is a mix of boulders around the edges, gravel, sand, and mud bottom habitat. The waters above Stellwagen Bank are full of life, as nutrient rich waters are pushed towards the surface by the rise of the bank and primary production flourishes. Although people often begin by describing the bank in terms of its depth and physical features, conversations soon drift to descriptions of the life these features support. One fisher described the area as a "garden" (Speaker 1), while another said, "it's almost like its own world out there" (Speaker 11).

Some fishers focused on the abundance of organisms such as whales, dolphins, fish, and seabirds, while others depict the area in more broad terms, saying, "the smell changes, the look of the water changes" (Speaker 2). A different person felt that although the resources are important, for them, Stellwagen Bank was and still is about the people. Multiple fishers I spoke with had been active in what is now the Sanctuary well before its designation and before the establishment of many current fishing regulations. When thinking back to these early scenes on the water one fisher summarized the space as home to its own unique community, saying, "We never see these people except on Stellwagen Bank because that was kind of like the hub of a wheel... So that's what it means, mostly, to me, is a place where one guy yelling at us in Italian, another guy yelling at us in Portuguese and somebody else yelling in English" (Speaker 10).

Given these histories of use and the unique geological feature that lies at the center of SBNMS, this area has never been considered "empty" in the way that other spans of deeper ocean floor have been portrayed (Rock et al. 2019). Instead, it is viewed as a valuable disruption in the nearshore habitat and a confluence of peoples, fish, and 
numerous other forms of marine life. Trade, fishing, and tourism are undeniably important, but people articulate meanings of Stellwagen Bank beyond one individual social or ecological element. Stellwagen Bank is a meeting place with multiple, often overlapping, and sometimes conflicting purposes and uses. Rather than defining this multiplicity of meanings, the boundaries of the Sanctuary were drawn around the central feature that itself drives these meanings. In addition, these meanings are not static. Stellwagen Bank, or Middle Bank, has borne witness to a myriad of cultural and/or tangible changes over the past thousands of years. However, despite any differences in how the bank has been used historically or in present day, consensus about the unique qualities of Stellwagen Bank is strong (Speakers 2, 8 11, 13). Yet consensus about how to manage SBNMS and protect life above and below the water is splintered and deeply tied to the context of the Sanctuary's designation in 1992.

\section{Sanctuary Designation}

Stellwagen Bank's designation in the fall of 1992 was the culmination of nearly ten years of work by groups such as the Defenders of Wildlife and the Center for Coastal Studies, as well as congressional delegates such as Representative Gerry Studds and Senator John Kerry. The long delay between the site's nomination to NOAA and the Sanctuary's final designation as part of the National Marine Sanctuaries Amendments Act of 1992 was likely due to multiple factors such as the need to build strong public support for the proposal and disagreements about where the Sanctuary's boundaries should lie (Borelli 2009) . In addition, it was reported that the U.S. Minerals Management Service (now the Bureau of Ocean Energy Management, Regulation and Enforcement) wanted to allow sand and gravel mining on the bank or at least for this type of extractive 
activity to be assessed on a case by case basis rather than prohibited outright through a new Sanctuary (Dumanoski 1992, Sanctuaries and Reserves Division 1993). Despite some internal federal resistance to designation, as proposals for mining and the construction of an artificial island and casino became public, support for the creation of the Sanctuary gained traction across political divides.

When asked to reflect on the designation process, one person described support for the Sanctuary as the result of an, "uneasy alliance of industry, conservationists, congressional delegates, and Massachusetts state delegates" (Speaker 6). While Stellwagen Bank's designation was directly related to the bottom habitat and rich

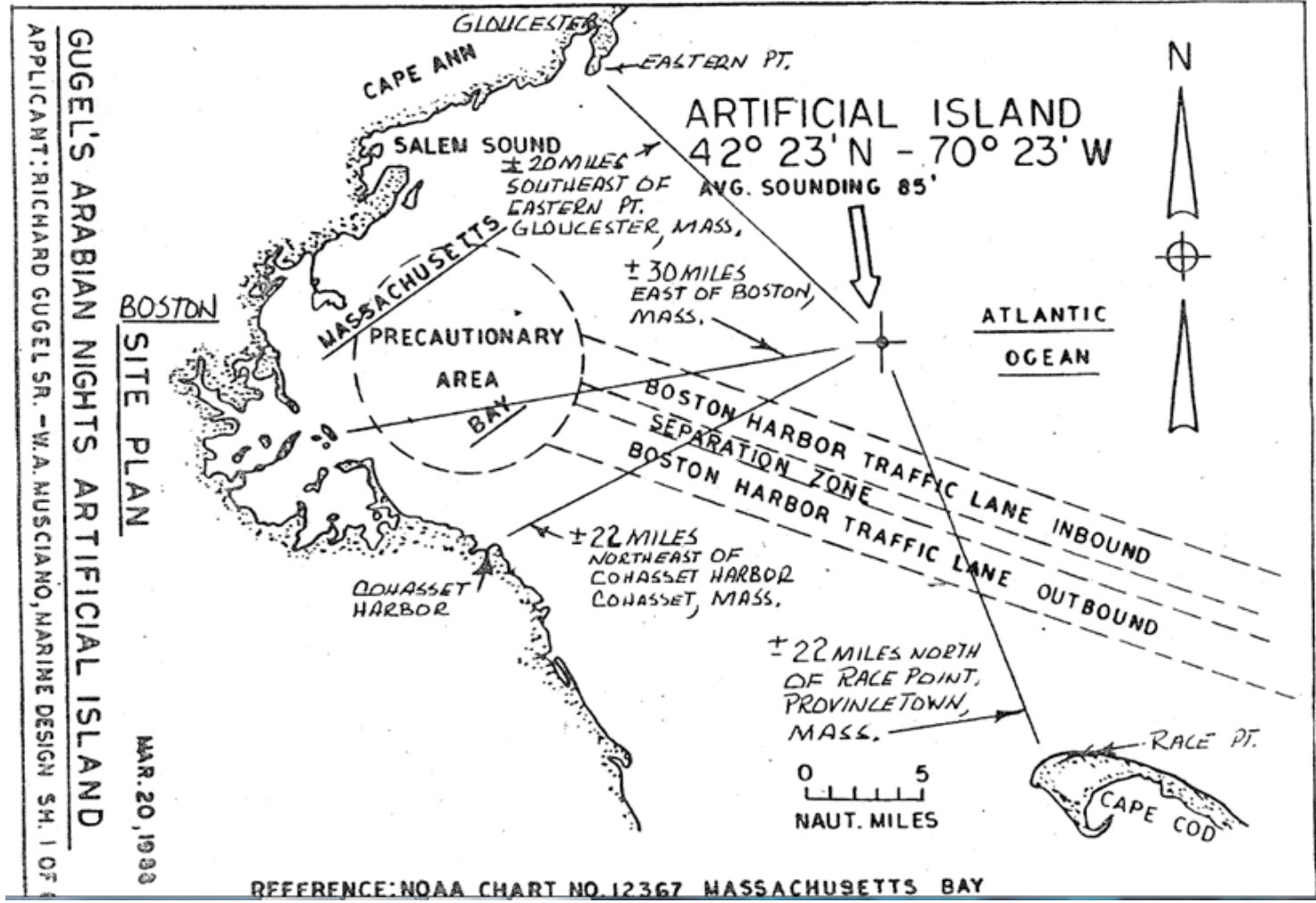

Figure 3. Image shows plans for the Arabian Nights Artificial Island and Casino. Image taken from PowerPoint by Assistant Professor Susan Farady of the University of New England.

resources that supported fishing and other commercial and recreational activities, there were no coordinated efforts to protect the area holistically prior to threat of development 
and mining. As one person summarized, "the Sanctuary was the means to the end" (Speaker 6). Commercial fishers were keen to protect vital bottom habitat from destructive uses, and many environmentalists, fueled by a growing body of research that supported the need for MPA development, were eager to enact long-term protections for a unique area under threat (Brody 1998, Speaker 6).

Baseline protections against dumping, mining, construction, lightering (transferring oil from one vessel to another), and damage to historic resources were relatively uncontroversial (Speakers 5, 6, 8). However, questions about the Sanctuary's role in shaping fisheries regulations sparked intense debate. Concessions by Sanctuary advocates to exclude fishing regulations in the designation document or list fishing as "subject to regulation" allowed the process to move forward. Rather than including specific fishing regulations or ruling out the possibility of future fisheries regulation, language in the designation document describes the Sanctuary as an institution created to fill gaps in the regulatory regime that would have allowed future industrial activities on Stellwagen Bank (Sanctuaries and Reserves Division 1993).

At the Sanctuary's official designation ceremony on sunny Oct. 26, 1993 in Plymouth, MA, Representative Studds and Senator Kerry, among multiple others, spoke about the importance of the Sanctuary's role in coordinating management efforts in the area. Others like Commerce Secretary Ron Brown said, "There will be no economic progress if we deplete economic resources," highlighting the linked social and ecological systems of the region (Telegram and Gazette 1993). Support like this from key politicians was essential in the Sanctuary's founding. In fact, given the success of the Sanctuary's approval, it was even rumored that then Vice President Al Gore would attend the event 
(although he did not) (Bigford 1993). However, the cheerful designation ceremony, marked by whale watch trips, exhibit fairs, and tours of the vessel Ferrel, and the broader alliance among politicians, fishers, and environmentalists, did not preclude ongoing and future debates about the purpose of the Sanctuary (Dedication Ceremony 1993).

\section{Current Perceptions of the Sanctuary}

Questions about the Sanctuary's purpose are reflected in early narratives of its designation. Despite the designation document which states that NOAA, "does not believe the imposition of Sanctuary fishing regulations would provide any constructive benefit to the issues currently addressed by other authorities" (Sanctuaries and Reserves

Division 1993, pg. 125), the depletion of fisheries resources was, at times, referenced as the reason why the Sanctuary was created. Speaking at the designation ceremony, U.S. Commerce Secretary Ron Brown said, "Three hundred years ago, fish were so plentiful that vast quantities could be harvested with nets placed in the harbors and rivers. But now, as with many of our national fishing grounds, Stellwagen Bank is in danger, with some species showing signs of actual stock depletion." (Telegram and Gazette 1993). A newspaper article described the Sanctuary as designed to "help protect the area from over-fishing and development" (Telegram and Gazette 1993). My own experiences on summer whale watch trips and in discussions with people who are not involved with fisheries management parallel these views about why the Sanctuary was created, as many people assume that resources within Sanctuary space are protected comprehensively including Sanctuary specific fisheries resources. 
While the creation of the Sanctuary may have been peripherally related to efforts to stabilize groundfish stocks that had collapsed in the late 1980s, the Sanctuary's lack of direct authority in regulating fishing is at odds with public perceptions about the Sanctuary's work. One person summarized this by saying, "I think it may appear to some who just came into the sanctuary world recently like, okay, it's a sanctuary, but it doesn't really conserve enough" (Speaker 12). Some people attribute the historical and ongoing confusion about the Sanctuary's purpose to the term, "sanctuary" itself. As one person said, "You hear sanctuary, you just automatically think of protection, you know? But guys are still dragging, lobstering, scalloping on the Sanctuary...you know what I mean? I mean I guess that's just the name of it, to me..." (Speaker 11). Perceptions of a sanctuary as off-limits, or a place of refuge were also common themes. One person even said, "you're operating from a disadvantage when the public thinks it's a sanctuary" due to the connotations of the word (Speaker 4), and another related the use of the term sanctuary to fears from commercial fishers that they will lose access to the space (Speaker 3). Even some people who are familiar with Sanctuary management at times expressed frustration about the term Sanctuary, highlighting the difficulty in completing work that feels at odds with the official label of the space.

In describing this tension between public perception and the actual work of the Sanctuary, one person referred to SBNMS as a "stealth sanctuary." Although they value the work of the Sanctuary because they are familiar with it, they felt that the Sanctuary is not using all available tools and that their work is often underappreciated by those outside of the management context (Speaker 6). Such disconnection from coastal communities surrounding Stellwagen Bank has been an ongoing challenge for SBNMS. Even in its 
early years, fresh off the success of designation, there are accounts of people wandering into the Sanctuary's newly established office in Plymouth, MA looking for an ATM because they saw the word "bank" on the sign outside (Speaker 2).

In addition, multiple people brought up the Sanctuary's location as a reason for its uphill battle for recognition. Unlike the Florida Keys National Marine Sanctuary, or others that are relatively close to shore, SBNMS is located twenty-five miles east of the Boston coast and three miles north of the tip of Cape Cod. As a result, access to the bank is restricted to those with the gear and knowledge to safely make the trip and to those who can afford tours or private charters. Although many coastal communities may be influenced by the resources of the bank, a relatively small proportion of people experience it firsthand. Thus, the challenge for SBNMS is to make many people care about a space that they often cannot see, may have never experienced, and that likely appears unrelated to their day to day lives (despite numerous social and ecological connections). To further complicate the situation, the Sanctuary, and more broadly the entire National Marine Sanctuary system, were often discussed as chronically underfunded (Borelli 2009, Speakers 2, 4, 7). This has serious impacts on the ability of the Sanctuary to consistently meet its mandate and live up to expectations.

Given this challenging context, most felt the Sanctuary and its staff are doing well in the face of considerable obstacles. Multiple people also stated that they believed the Sanctuary was shifting in both purpose and profile (Speaker 4, 7, 8). Over time, the Sanctuary has established credibility in its research efforts and is viewed as slowly but surely gaining wider public recognition. Changes in its public profile have been attributed to the merits of individual staff members, increased presence through outreach, and a 
perceived shift in the Sanctuary's willingness to build (or in some cases rebuild) relationships with the range of people who use the Sanctuary, both recreationally and commercially. The appointment of a new Sanctuary superintendent, retired Coast Guard Captain Pete DeCola in the fall of 2018, along with the upcoming 2020 management plan review process were also listed as potentially positive opportunities for change (Speakers $3,8,13)$. The positive perceptions of these two tangible changes, combined with a gradual increase in the Sanctuary's public visibility, provide important insights into why people view the Sanctuary's presence as growing. The positive changes listed across interviews and witnessed through my own experiences also highlight the hope that people see for the future of the SBNMS.

To capitalize on this hope the Sanctuary must address the dissonance between internally positive perceptions of the Sanctuary's work and external confusion about the Sanctuary's purpose and the extent of its authority. Deep internal reflection now, may allow the Sanctuary to clarify and reimagine its role in the protection of Stellwagen Bank. To continue to work towards an institution capable of long-term protection requires grappling with the social complexities of managing an area with multiple, simultaneous, and sometimes conflicting, uses and meanings. Through the remaining sections of this document, I explore social and political themes that have shaped the management of SBNMS over time at the federal, regional, and local scales to begin to untangle how different relationships, groups of people, and individuals impact management possibilities. I will also begin to answer questions about what constitutes protection in this space. In an announcement about the designation, Congressman Studds summed up the reasoning for the Sanctuary by saying, "It's good news for the whales, it's good news 
for the fish, and it's good news for the people who live here..." (Chaffee 1992). Yet, rather than try to classify the Sanctuary as either good or bad, it is important to iteratively ask who it serves now and how it could be improved to ensure that past notions of its purpose do not hold it back from its potential role in the long-term protection of Stellwagen Bank’s cultural and natural resources.

\section{CHAPTER 2: Legal and Institutional Framework}

National Marine Sanctuaries Act (NMSA)

Immediate relationships, such as those among Sanctuary staff, SAC members and people who recreate and/or work in the Sanctuary, are undoubtedly important to the management of the SBNMS. However, the overarching relationship between the Sanctuary and the federal laws and offices that guide the Sanctuary's mandate was also discussed in my interviews and in the Sanctuary's office as an important backdrop for the current state of the Sanctuary. While this dynamic between the Sanctuary and the federal authorities that govern it may seem obvious to those who have experience with the Sanctuary system, how individual Sanctuaries interpret the broader mandate of the National Marine Sanctuary system and navigate relationships with supervising offices and other sanctuaries is less than clear to those external to the process. For some people I spoke with, understanding this larger federal regulatory context was crucial for understanding the SBNMS. Specifically, ambiguous language within the National Marine Sanctuaries Act (NMSA) was cited as driving both system wide challenges in management and issues specific to SBNMS. While flexibility in the NMSA may allow a sanctuary to adapt to local needs, it is feared that the lack of clear purpose for Sanctuary 
sites or clear methods through which to make decisions about how to balance multiple uses of a space can also be detrimental to their effectiveness in providing long-term protection.

For example, in discussing the Sanctuary's current role in fisheries regulation and any potential shift in towards the Sanctuary gaining increased input into fishery-related decisions one person stated, "It would require somebody in Washington to actually say, 'Actually, this designation does allow you to do this [work to regulate fishing] under what the National Marine Sanctuary Act calls for, and what your vision statement calls for'" (Speaker 4). Although it is not specifically referenced, this statement illustrates the underlying requirement to prove that an activity is harmful to restrict it rather to prove that an activity is safe in order to allow it. This default acceptance of the status quo is at the center of debates around how SBNMS should protect the Bank. As one person explained when discussing why the Sanctuary had not developed stronger on the water protections over time, it was "politically a little too difficult for the folks at NOAA to deal with" (Speaker 6).

In addition to the influence of political support, criticisms of the NMSA largely center around the lack of clear authority or "teeth" (Speaker 6) in the law that prevents staff within the sanctuaries system from pursuing protection consistently. Unlike the Wilderness Act of 1964 which clearly lays out goals for management and preservation of wilderness, the NMSA has multiple objectives that are at times contradictory (Chandler and Gillelan 2007). For example, in Section 301(b)(3), the NMSA states one of its purposes as, "to maintain the natural biological communities in the national marine sanctuaries, and to protect, and, where appropriate, restore and enhance natural habitats, 
populations and ecological processes" (NMSA 2000). While most other sub-sections listed under this Purposes and Policies header relate to conservation or management in ways that align with this initial goal, Section 301(b)(6) opens the door for potential conflict. It states that an additional goal of the NMSA is, "to facilitate to the extent compatible with the primary objective of resource protection, all public and private uses of the resources of these marine areas not prohibited pursuant to other authorities" (NMSA 2000).

Section 301(b)(6) begins by declaring "resource protection" as the primary goal of the sanctuary system, but the added mandate to facilitate other uses dilutes this objective and raises critical questions about how to decide what is compatible and what is not. As one person summarized, "There's no one consistent vision for what a sanctuary should be" and "all the sections have this sort of identity crisis" (Speaker 6). In conversations with people about the purposes and goals for sanctuaries, rather than referring to a recognized standard, multiple people used examples from sanctuaries across the system to compare and contrast with SBNMS. For instance, fishers weary of increased regulations often referenced the Florida Keys National Marine Sanctuary or the Monterey Bay National Marine Sanctuary as examples of both positive and negative processes for developing fisheries regulation. In one instance, a recreational fisher's view on the processes in Florida led them to be concerned that similar management action and a "PR [public relations] campaign" like the one in Florida could take place in SBNMS (Speaker 10). ${ }^{1}$ Similarly, opposition to potential recreational diving regulations were

\footnotetext{
${ }^{1}$ The Florida Keys National Marine Sanctuary finalized a marine zoning plan in 1997 that regulates where and how recreational fishing can take place. Although this process has been heralded as an example of a successful public process, Speaker 10 felt that it was a well-executed public relations campaign rather than an instance of meaningful inclusion of the voices of recreational fishers.
} 
related to the Monitor National Marine Sanctuary, and both support and opposition regarding whale watch tour guidelines were related to the Channel Islands National Marine Sanctuary. While there are some consistent requirements for sanctuaries, such as public scoping and public comment periods for management plan reviews, how decisions are made beyond these larger, formal processes in different sites is less clear.

The unresolved contradictions in the NMSA and the disjointed management actions and processes across Sanctuaries have important implications for enforcement. While it is not unusual for MPAs to include multiple uses, the conundrum of the NMSA lies in the sparse guidance on how Sanctuaries should act given this nebulous directive and a general reluctance by the Secretary of Commerce or the Office of National Marine Sanctuaries to utilize the open language of the NMSA to advocate for stronger restrictions on use (Chandler and Gillelan 2007). As authors such as Chandler and Gillelan (2007) illustrate, the multiple use clause in the NSMA can also be co-opted by industry interests and lobbyists to argue for no prohibitions on activities within sanctuaries or interpreted as a right to activity rather than context dependent privilege. As one person pointed out, managers are inclined to abide by the mandates of other federal legislation such as the Clean Water Act and the Magnuson-Stevens Act because, "That's what they get sued under" whereas the NMSA provides ample grey area that would make legal action more difficult (Speaker 6). Given this context, one person felt that even if the NMSA itself could not be substantially altered to clarify how sites should balance multiple uses, the ONMS giving guidance on decision making processes and saying, "we're going to help you figure out how to do that" would be "huge" (Speaker 4). 
While it is likely that guidance documents or recommendations about how to make decisions exist in some form across sites, consistency across the Sanctuary in terms of process, if not outcomes, was described as lacking by some interviewees (Speakers 2, 4). The grey area that constitutes compatible use varies from sanctuary to sanctuary, and it is typically shaped by regulations outlined in a site's designation document and/ or management plan (Farady 2006). Even though the Sanctuary published a hypothetical Sanctuary Compatibility Analysis Process (S-CAP) in 2010, it is unclear if and how this process has been applied (Figure 4, ONMS 2010, pg. 217). Although this question was

\section{Figure 127. HyPOTHETICAL APPLICATION OF S-CAP PROCESS.}

Issue: Does ' $x$ ' activity in the SBNMS harm marine mammals? Is it a use compatible with the sanctuary's purpose?

Vision: Ecological integrity is protected. Mission: Resource protection

Goal: Protect assemblages of marine mammals

Objective: Strengthen the protection of marine mammals by assessing and minimizing behavioral disturbance, including vessel strikes to and entanglement of marine mammals, and by fostering cooperation with cross-jurisdictional partners whose activities could impact marine mammals.

Standard: Marine mammal behavior is not altered and marine mammals are not struck or entangled by ' $\mathrm{x}$ ' activity. Indicators that standard is being achieved:

- No marine mammals are struck or entangled by ' $x$ ' activity.

- No change in marine mammal distribution due to ' $x$ ' activity.

- Surface-to-dive time ratio for marine mammals is within normal range and unaffected by ' $x$ ' activity.

- Marine mammal communication is unimpeded by ' $x$ ' activity.

Figure 4. Figure. This figure was taken from the Sanctuary's 2010 Final Management Plan and Environmental Assessment (ONMS 2010, pg. 217, Figure 127). It shows an example flow of decisions related to an activity in the Sanctuary.

not asked directly, interviewees related to Sanctuary management through the SAC did not articulate detailed mechanisms through which decisions were discussed or made. While it is possible that this project simply failed to capture details around decisionmaking processes, the lack of publicly available information about how specific issues have been deemed compatible or not is worthy of attention. Individual managers and Sanctuary staff were also discussed as an important influence on the level of communication about decisions and the overall direction of the Sanctuary. 
Collectively, the lack of coherent federal vision for the sanctuary system and the frequent comparison among sanctuary sites may suggest that the National Marine Sanctuary Program is guided by precedent and individual sanctuary leadership rather than a broader consensus about basic sanctuary purposes and goals. In sanctuaries with strong community support or strong NGO support, this context dependent management style may be a benefit, as sites can tailor their management to local and regional needs and interests. However, for sanctuaries such as SBNMS, the absence of a robust structural framework for management may mean efforts to implement long-term protection are undermined by the flexibility of the NMSA and the strength of short-term local interests that favor extractive use.

While there is no universal solution for resolving the disconnection in federal and site-specific goals for resource protection, increased clarity in the NMSA with regards to the primary objectives for sanctuaries and system-wide protocols for decision-making would help establish a solid foundation from which to act. Multiple people I spoke with considered changes to the NMSA in the near future unlikely. SBNMS itself may have little power to impact system-wide structures for decision-making, and efforts to increase transparency and communication around important Sanctuary decisions will likely be constrained by staff time and funding. However, clarifying how criteria or workflows such as the S-CAP are actually applied to individual topics would be a useful first step in making Sanctuary decisions about compatibility visible to people beyond managers or the sanctuary advisory council (SAC). Additionally, presenting information about compatibility in a way that is accessible and easy to understand is necessary, as what information is available is primarily written for internal or scientific audiences (Dalton 
2005). This regulatory context and the current weaknesses in the NMSA are particularly relevant when considering contentious issues in SBNMS such as fisheries management.

\section{CHAPTER 3: Statues by the Sea and the Legacy of New England Fishing}

The Sanctuary's ability to protect Stellwagen Bank is shaped by the federal structures that govern the broader national marine sanctuary system, but it is also strongly shaped by the political and cultural forces within New England. Although New England lands and waters have provided valuable raw materials to sustain life for thousands of years, histories of fishing peoples and communities in the region are often dominated by stories of white European settlers braving the cold Atlantic waters. The importance of this era of fishing is deeply ingrained in the identity of many coastal New England towns, both economically and culturally (McKenzie 2018). As a result, commercial and recreational fishers play a substantial role in granting an organization's social license to operate, or in dictating the level of social acceptability for the actions of an agency like NOAA or a NOAA office such as the Sanctuary (Dare et al. 2014).

While the Sanctuary and the National Marine Fisheries Service (NOAA Fisheries) do have some overlapping jurisdiction related to issues such as marine mammal protection, they are distinct entities (ONMS 2010). In the Sanctuary's most recent Condition Report (2020), these separate duties are made clear and it is explicitly stated that, "SBNMS does not manage fisheries in the sanctuary" (ONMS 2020, pg. 50). Instead, fisheries management plans and policy are developed by the New England Fishery Management Council (NEFMC), the Mid-Atlantic Fishery Management Council (MAFMC), the Atlantic States Marine Fisheries Commission (ASMFC), and NOAA Fisheries depending on species and location (ONMS 2020). Despite this definitive 
statement, the role of the Sanctuary in fisheries management has not always been so clear. Confusion and debate about how the Sanctuary should operate in relation to other regional and federal authorities, combined with layers of regional history related to the Sanctuary's designation help complicate present understandings of fisheries management in Sanctuary space. Understanding how the Sanctuary has acted, and not acted, given this regional context will be useful as decision makers work to define Sanctuary goals for the coming years and the Sanctuary's role in managing the marine environment of Stellwagen Bank.
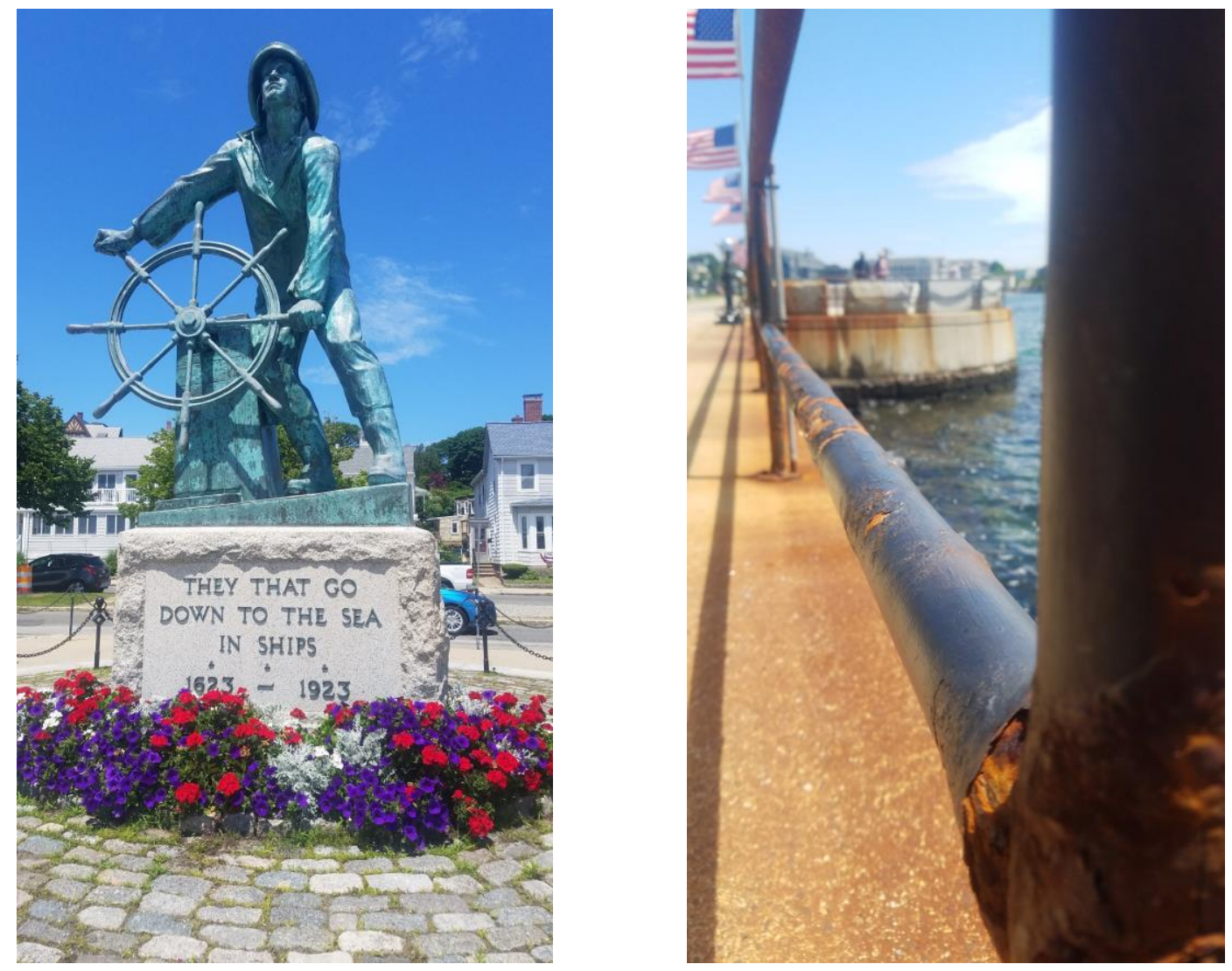

Figure 5. (left) Gloucester Fisherman's Memorial, (right) Gloucester boardwalk) July 2019. Photos by Clea Harrelson.

Various forms of fishing take place along the coast of Massachusetts Bay and within the larger Gulf of Maine, but centers of industrial and political power closest to 
SBNMS are concentrated in a few well-known port towns such as New Bedford, MA, Provincetown, MA, Gloucester, MA. I visited Gloucester for the first time shortly after the 4th of July in 2019, and American flags still flapped in the breeze along the boardwalk. Although the streets and the waterfront were relatively empty, multiple small groups were hovering around one section of the boardwalk. As I got closer, I could make out the Gloucester Fisherman's Memorial, a bronze figure of a man dressed in oilskins, clutching the wheel of his ship and looking out to sea. People politely lined up to take turns smiling next to the seemingly timeless figure, framed by flags and flowers. Although the statue was erected in 1925 to commemorate fishers who died at sea from 1623-1923, it has become emblematic of the broader culture of New England fishing, attracting thousands of visitors annually (Gloucester Fisherman's Memorial n.d.).

When asked about what makes the context of SBNMS and New England unique, one person referenced this form of memorialization as important, saying, "it's the statues," indicating that for many involved in fishing and fisheries regulation, the prominence of historical New England fishing in the 1900s is an impenetrable monolith, much like the Gloucester Fisherman's Memorial (Speaker 6). Proposals for change in access to fisheries resources are often countered with historical use as evidence for why that change should not occur. This person, along with authors such as McKenzie (2018), view the ways in which fishing history is leveraged in discussions of fisheries management as an impediment to more balanced conversations about resource use and how to prioritize longer timescales in resource management.

While the political framework that separates fisheries management from management of SBNMS may not change in the near future, the Sanctuary still plays an 
important, if indirect, role in fisheries management. Avenues such as ecological research offer more obvious opportunities to support and influence fisheries management, but how fishing activity and history is represented is an additional point of entry into how current management came to be, and thus, how it might change. A strong focus on what is primarily white settler fishing in New England raises important questions about whose history is being told, and how narratives of historical fishing practice frame current understandings of fisheries management.

Although diversity in gear, boat size, and target species is commonly reported, diversity in who is fishing is often absent from management conversations. Additionally, historical New England fishing is often portrayed by fishers and fisheries lobbies through the lens of 20th century fishers, with short asides about the industry's colonial roots (McKenzie 2018, Speaker 9). Preservation of particular historical threads occurs through statues such as the one in Gloucester, MA but also through the Sanctuary's own research on shipwrecks which primarily catalogs ships built by Americans from the mid-1800s onwards. While many shipwrecks within the Sanctuary, such as the Portland, are not fishing vessels, the range of ships related to energy or passenger transport are still tied to $20^{\text {th }}$ century industrial development and information is largely focused on function as opposed to people. This focus on shipwrecks is, in part, a result of visibility, as the location of many shipwrecks is already well known by fishers, making the shipwrecks an easy starting point in documenting the history of the Bank. When asked about maritime heritage at the Sanctuary, one person described this focus on shipwrecks as natural, "because that's really the primary archeological resource we have" (Speaker 7). Shipwrecks from the past century also represent tangible ties to the range of maritime 
activities that took place on and around Stellwagen Bank and help illustrate the very real importance of coastal travel and fishing in the economic development of the region (ONMS 2010).

Shipwrecks from the 1800s through present can be a valuable source of information about how interactions and use of Stellwagen Bank have changed over time, but to capture a more robust understanding of how those ships came to be and how the current uses of Stellwagen Bank evolved, the histories of Stellwagen Bank must be expanded. The Sanctuary has been actively developing its maritime heritage program since 2000 and hired full-time and part-time maritime archeologists from 2002-2016 to coordinate their maritime heritage research (ONMS 2010, Speaker 7). This program was spurred both by changes in staff as well as the Sanctuary's mandate to comply with the Nation Historic Preservation Act of 1966 and later President Bush's Preserve American Act (Executive Order 13287, 2003). And yet, despite over a decade of focus on maritime heritage, Sanctuary research on indigenous peoples of Massachusetts Bay or demographic diversity in coastal communities beyond descriptions of gear or recreational vs. commercial use remain sparse. While this is not unique given the parallel gaps in research for the broader Gulf of Maine, it still noteworthy.

Terrell's 1994 text, Fathoming Our Past: Historical Contexts of the National Marine Sanctuaries, produced through the Sanctuaries and Reserves Division (now the Office of National Marine Sanctuaries) remains the central public source of information about early people and the paleo-shorelines that existed on what is now Stellwagen Bank. Although evidence suggests the possibility of human cultural remains, one person said, "we haven't actually found that [evidence] or looked for it" (Speaker 7). But research and 
experiences beyond the Sanctuary's own work, such as fishers towing up mastodon skeletal remains on Stellwagen Bank (Terrell 1994) and research undertaken as part of the Rhode Island Ocean Special Area Management Plan that explores reconstructed paleo-landscapes (RI CRMC 2010, pgs. 61-63) and examples of other coastal archeological research in New England help demonstrate the possibility of human resources yet to be discovered (Bernstein 2006, Bolster 2006, Merwin et al. 2003, Waller 2000). Additionally, technological advances in maritime archeology may offer insights into the histories of Stellwagen Bank in ways that may not have seemed feasible at the outset of the Sanctuary's maritime heritage program (Bell 2009).

Exploration of the Sanctuary's past beyond shipwrecks and/or commercial activity is valuable in and of itself, but it is also an important step in helping correct erasure and histories of Massachusetts Bay that depict indigenous coastal peoples such as the Massachusett, Wampanoag, and other regional tribal nations as existing only in the past or that ignore their past and present existence entirely. This erasure has been linked in indigenous academic literature to, "a desire to remove indigenous peoples in order to access resources and land" (Hall 2008, Orr et al. 2019, pg.2). Even when acknowledged, indigenous scholars such as Bruchac et al. (2016) point out that archeological research that focuses only on detached metrics of mobility and trade networks can dehumanize the people who lived and the people and cultures that live on. The Sanctuary has had notable success in bringing the passengers of the ill-fated ship the Portland to life (Gillian 2019, Lawrence et al. 2015), and could use similar methods in public communication to help people connect to histories beyond the settler colonial timeframe. 
Further, because recognition, rights, and sovereignty for Native American peoples are closely tied to the historic record and continuity of occupation, how SBNMS portrays, or does not portray native peoples is significant to their ability to live, work, and play on their ancestral homelands (Bernstein 2006, Silliman 2009). While Sanctuary programs such as the camp day organized as part of the Mashpee Wampanoag Tribe Preserving Our Homelands Science Camp indicate recognition of the need for engagement with the multiplicity of communities who rely on Stellwagen Bank's resources, in depth analysis of indigenous histories or public representation of this information is lacking. This is apparent in documents such as the Sanctuary's 2010 management plan as well as in the Sanctuary's website and public outreach materials in which coastal native peoples are commonly listed in a brief historical framework.

A view of New England fishing history and culture that is limited to 20th century activity and primarily white fishers additionally obscures the longevity and dynamism of resource use on Stellwagen Bank and helps reinforce a narrative of the permanence of current forms of fishing. If heavy, unsustainable fishing pressure is understood by the public as something that has always been, then it is viewed as normal and inevitable. As a result, historicizing fishing on Stellwagen Bank through the inclusion of indigenous peoples and other marine user groups, past and present, challenges the seemingly sanctified and untouchable image of white commercial fishers presented by statues such as the Gloucester Fisherman's Memorial for both SBNMS and the broader region within which the Sanctuary is embedded.

Although the romanticized view of New England fishing is often leveraged to protect fishers from perceived economic hardships or further regulation, the stagnant 
view of a lone, heroic fisher attempting to carve out a living from the sea can also be limiting for fishers themselves. People who have experienced a tremendous amount of change in fisheries management in recent decades and face increasing threats of consolidation and overfishing are failed by a flattened, satic, and antiquated view of their profession. If a fisher's life has always been depicted as difficult, then recent changes may appear normal to those whose lives do not directly rely on the industry. Threats of neoliberal corporatization/consolidation, increasing costs of operation, climate change, and the ability of MPAs like the Sanctuary to enact ecosystem scale protection, among other issues, were important to fishers I spoke with over the course of this project (Speakers 9, 10). Although managers and public audiences are likely generally aware of these issues, there was a sense that the general reliance on broad industry indicators such as the total annual value of a fishery help mask the impacts of these changes on small scale operators.

Finally, through exploring the complexity of coastal and maritime lives in the past and present, the Sanctuary has an opportunity to reconnect broader constituencies with the coast by illuminating experiences of work and play beyond fishing. By disrupting a simplistic view of fishing in New England, the Sanctuary can begin to build support for stronger protection or protection that meets the needs of many different people and groups. As Bolster (2006, pg. 571) summarized, “The oceans' current crisis resulted from a century of vigorous fact-finding by scientists along with managers' reliance on numbers divorced from context, and politicians' satisfaction with exceedingly short-term solutions. If there was ever a dilemma crying out for historians' sensibilities, this is it." 
Although lack of funding is a pervasive concern when it comes to supporting and managing the Sanctuary's projects, perpetuating the erasure of indigenous peoples through inaction and inadequate historical context of the diversity of past and present day resource users is also costly in terms of how the dominance of a particular view of New England fishing impacts support from the public and the fishing industry. While fishing activities may be a fruitful starting point for this research, native peoples and others who live along the coast that borders Stellwagen Bank undoubtedly use Sanctuary resources in a variety of ways, and the prominence of fishing in conversations of resource use should not negate exploration of other connections to this space.

\section{The Promise}

In conjunction with the broader, regional dynamics of the Sanctuary's history, the more immediate story of the Sanctuary's designation is an important, and evolving, influence on its current distance from fisheries management practices. In discussions about the Sanctuary's role in fisheries management, one story was brought up more than any other: the Promise. The story of the Promise involves a range of actors, including New England congressional delegates, Sanctuary advocates, NGOs, and prominent fishing industry representatives. It represents different things to different people and was used to explain why the Sanctuary should or should not be involved in fisheries management as well as to argue for increased Sanctuary outreach. Perhaps most importantly, the meaning of the Promise was described by multiple people as in flux. I found that the context of changing environmental conditions as well as the presence or absence of certain? people altered how the impacts of the Promise were viewed. 
In the late 1980s and early 1990s, the fishing industry expressed strong opposition to the Sanctuary's designation. Given the power of the fishing lobby at that time, the congressional champions of the Sanctuary, Congressman Gerry Studds and Senator John Kerry, among others, felt that the Sanctuary's designation would not be politically feasible without the industry's support. One person described attitudes at that time as, "you have to give up something to save something" (Speaker 5). In order to move the designation forward, fishery representatives and Sanctuary advocates brokered a deal. As one person summarized, an uneasy alliance of groups came together in a university office in 1991 and shook hands on an agreement to exclude explicit fishing regulations from the Sanctuary's designation document (Speaker 5). The Final Environmental Statement and Management Plan produced in 1993 states, "NOAA/OCRM [Office of Ocean and Coastal Resource Management] does not believe the imposition of Sanctuary fishing regulations would provide any constructive benefit to the issues currently being addressed by other authorities" (Sanctuaries and Reserves Division 1993, pg. 125). As the primary fear of many fishers was, and continues to be, loss of fishing access, this meeting was pivotal in uniting fishers with conservationists against the common threat of gravel mining and nonfishery-based commercial development.

Despite this promise, tensions remained high, and in that same year, a fisher who claimed, "special knowledge of the designation process" made calls to other fishers urging them to not put their trust in "NOAA folks" (Bigford 1991). Overarching distrust of NOAA was central to fishers' concerns throughout the designation process, but multiple people also stated that individual Sanctuary staff members were an important factor in early relationships with the fishing industry and fisheries managers. Although 
advocates for the Sanctuary had promised only a few years prior that the Sanctuary's creation would not impact the fishing regulations already in place through the regional council, questions of who had made that promise and the scope of the promise are contested. While some interpreted the Promise as the Sanctuary's indefinite abdication of authority related to fisheries management, others took it to mean that the Sanctuary would work closely with the New England Fishery Management Council (NEFMC), the Greater Atlantic Regional Fisheries Office (GARFO), and other relevant agencies in the development of fisheries policies. This lack of consensus around the Sanctuary's role in fisheries and clashing differences in individual personalities of Sanctuary staff and leaders of other regulatory bodies may have played a role in shaping what are perceived as negative initial interactions between the Sanctuary and other regional authorities such as the NEFMC. However, one person related to NOAA also described an underlying reluctance to make space for the new institution saying that upon entering a meeting they were told by a fellow NOAA representative, "If you want something said, you say it to me and then I will say it if I think that it's worth saying" (Speaker 2). 
Although current relationships between Sanctuary staff and other regional authorities are described in a significantly more positive light, the underlying discord related to the Sanctuary's involvement in fisheries management has not evaporated. One person underscored this by saying commercial fishers appear with newspaper articles and quotes about the Promise, "the minute there's any mention of the sanctuary doing anything to restrict fishing out there" (Speaker 6). Further, in addition to commercial fishers, the power of recreational fishers has grown over the past decade. While they were not discussed within stories about the Promise, some recreational fishers also leverage the Promise and the purpose of Stellwagen's designation to oppose new Sanctuary specific fishing regulations. The specter of the Promise was raised most recently in 2015 when the Sanctuary advocated for the creation of the Stellwagen Dedicated Habitat Research Area (DHRA), including a small no-take zone. One person recalled thinking, "Wait a second, this is inconsistent with what we were promised" in describing the dismay from fishers who saw the Sanctuary as overstepping its bounds (Speaker 13). Although the DHRA was officially enacted by the NEFMC in 2018, the approval is largely symbolic as the DHRA is located entirely within the existing Western Gulf of Maine Groundfish Closure Area, has no additional restrictions to commercial fishing, and is open to recreational charter and party boats (Speaker 7).

Lack of support for stronger restrictions in the DHRA is related to the Promise and views of the Sanctuary's role in fisheries management, but opposition also stemmed from broader questions about the utility of managing fisheries differently in such a small area and the nature of the Sanctuary's public processes. While advocates for no-take reserves within the Sanctuary view stricter regulations and areas with no direct harvest as 


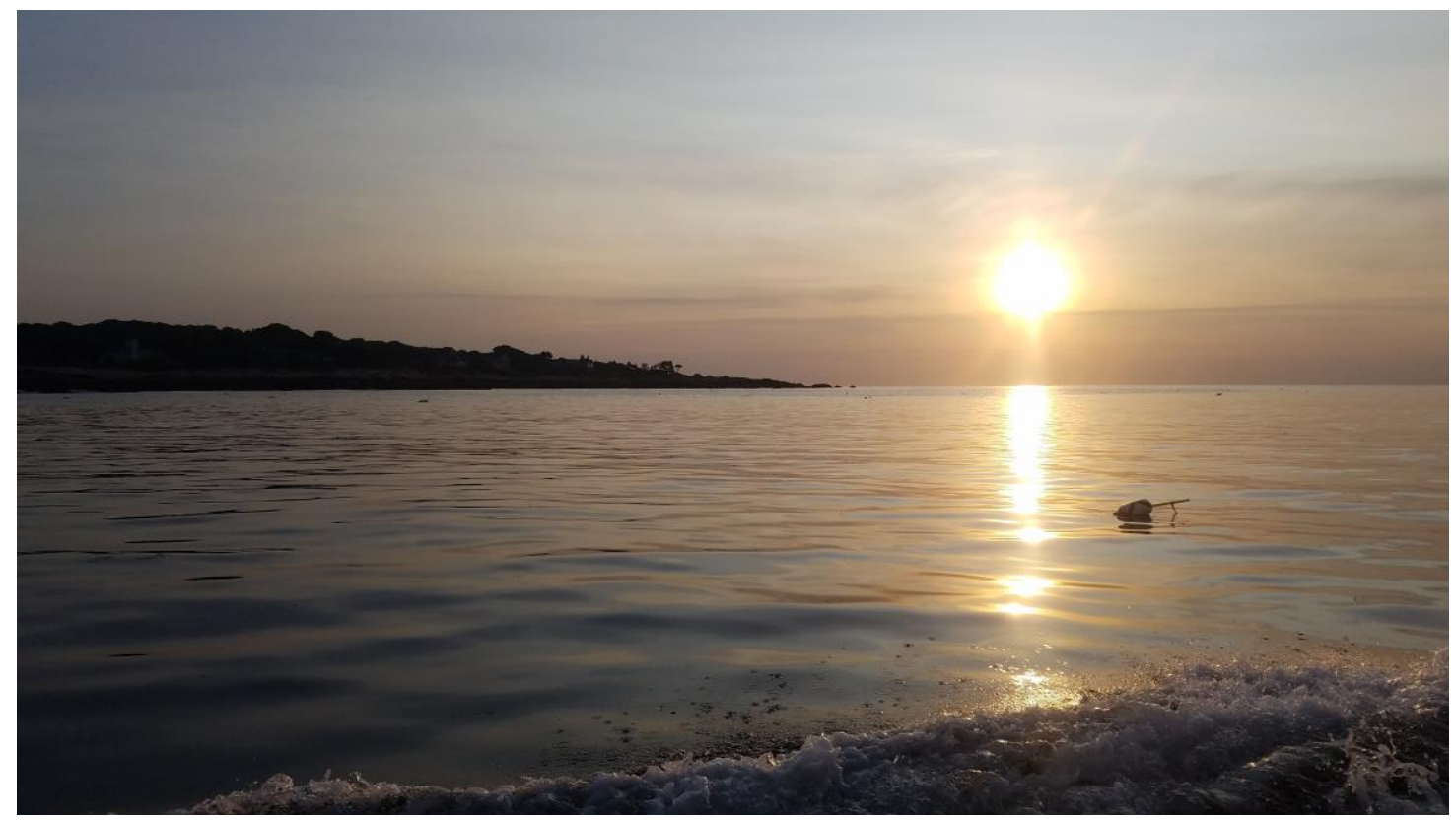

Figure 6. Sunrise on waters just off the shore of Gloucester, MA July 2019. Photo by Clea Harrelson.

a necessary safeguard against overexploitation, one fisher said, "we really need to take care of the whole ocean, not just 600 and odd square miles of it" (Speaker 10). This same person followed up by stating, "it's really ironic that I literally have more history there than a lot of people and they're saying no, you're a human, you don't belong in that ecosystem; I was there for 50 years. That doesn't count. I wasn't dealing with mastodons who were walking around when it was dry land" (Speaker 10). Another person stated that they did not support Sanctuary involvement in fisheries management because other bodies such as the NEFMC have, "a public participation process that we're comfortable with" (Speaker 13). Concern about representation was often tied to stories of past issues with specific staff members and while one person in the Sanctuary office acknowledged the importance of the Promise, they said that they, "haven't heard anyone invoke the Promise for a long time." However, it is unclear whether the extent to which invocations of the Promise decreased because of changing attitudes about the Sanctuary's role in fisheries management or as a result of changing Sanctuary goals related to fisheries 
management. Additionally, conversations with fishers about the Promise frequently turned into discussions of the hope sparked by the Sanctuary's efforts to rebuild relationships with the commercial and recreational fishing communities through outreach and the appointment of the new superintendent, Peter DeCola.

Given this context, opposition to the Sanctuary's involvement in fisheries management may be more strongly related to contested views on the overarching role of the Sanctuary in fisheries management and the perceived fairness of input rather than specific objections to a particular management action. Ongoing and future research to map changes in the biological resources of Stellwagen Bank is essential to support the Sanctuary's mission. However, renegotiating the place of SBNMS within the context of New England fishing and rebuilding/building strong relationships with fishers of all types is the necessary foundation that will allow Sanctuary research to be applied.

People discussed the Sanctuary as already in the process of rebuilding relationships with fishing communities. However, lingering misconceptions about the Sanctuary's current role in fisheries management may serve to keep fears that fishers would lose access to Stellwagen Bank fishing ground alive. Clear concise, messaging in the form of flow charts, graphs, or other imagery to demonstrate the relationship among various branches of NOAA agencies and the Sanctuary could be a useful tool in working to combat these misunderstandings. Additionally, efforts to help illuminate the historical and ongoing fishing by indigenous peoples, as well as the diversity of non-indigenous contemporary fishers could be an critical first step in understanding resource use as an ever-evolving relationship with the marine environment rather than a static way of life. While Sanctuary funds for supporting social science and historical research internally are 
limited, it has had past success with community and academic partners that may provide footing for new projects. At the very least, expansion of maritime heritage work beyond shipwrecks could be identified in the upcoming management plan draft as a long-term goal to signal to other institutions and potential partners intentions to broaden the Sanctuary's scope of research.

\section{CHAPTER 4: In Search of Representation}

In addition to the impacts of federal and regional social contexts on SBNMS management, individuals and relationships at the institutional level were also discussed as key factors that swayed the direction of management. In particular, relationships among Sanctuary Advisory Council (SAC) members and between SAC members and Sanctuary staff were viewed through the lens of past discord but also as an opportunity for growth. Additionally, some related the structure and processes of the SAC to current management challenges and felt that changes to the SAC could positively influence overall management and Sanctuary support. At their best, SACs can reduce the information asymmetry among participants, provide a structured platform for feedback by groups of people most impacted by Sanctuary decisions, and provide Sanctuary staff with valuable expertise to supplement decision-making processes (McDonald and Gallagher 2015, SBNMS SAC Charter 2018). While the SBNMS SAC was viewed as falling short of these ideal outcomes, people who have experience with the SAC process (serving now or those who served in the past) viewed the SAC as an important feature of Sanctuary management with tangible options available for improvement.

The SBNMS SAC consists of seventeen non-governmental representatives (voting), one youth representative (non-voting), and six governmental appointees (non- 
voting) that meet three to four times a year depending on funding and need. The Sanctuary originally established a SAC in 1992, and then re-established the structure in 2001 after a lapse related to the change in superintendents (Basta 2005). The council elects a chair, vice-chair, and secretary to guide meeting operations from within the pool of non-governmental seats (non-voting members are allowed to participate in the election). Meetings are open to the public, and decisions are made based on majority vote. The role of the SAC as outlined by its charter is to provide "advice and recommendations" to the Sanctuary superintendent and serve as "liaisons between their communities and the Sanctuary" (SBNMS SAC Charter 2018). Broadly, concerns about the function and effectiveness of the SAC relate to both processes of communication and the significant impact individual people can have on those processes.

Efforts to increase public participation in MPA management are not new and have increased steadily in recent decades (Brody 1998, Dalton 2005, Kaza 1988, Reed 2008, Voyer et al. 2013). Within debates about how to best integrate the values of a wide range of people with vested interests in a space, questions related to the extent to which agreement is beneficial are common (Peterson et al. 2005). Although the SAC at SBNMS makes most decisions based on a majority vote as opposed to consensus (some working groups may seek consensus), some people were still concerned with the illusion of consensus that can result from voting outcomes. Because the distribution of seats is relatively unchanging (although not permanent), one fisher felt that because there were more seats allotted to people who are likely conservation oriented, the presence of fishing seats was largely symbolic rather than meaningful (Speaker 13). In contrast, another SAC member expressed frustration with what they perceived as regulatory capture, or the 
dominance of fishing industry representatives in the management of marine resources overall. They felt that to truly achieve more balanced representation, more seats on the SAC should be given to those representing the natural resources of the sanctuary, including right whales, herring, cod, and haddock" (Speaker 4). In addition, multiple people viewed the Sanctuary as an important potential check on what they perceived as an industry dominated regulatory landscape in which short term economic gains are commonly prioritized over long-term protection. For both those who advocate for increased on the water Sanctuary protections and those opposed to further regulation, the process of voting and the endorsement of a subsequent decision was associated with what Cairns et al. 2014 refers to as a "false universalism."

Rather than the process leading up to a vote creating shared understandings of an issue, there was a sense that the process only served to further entrench individual beliefs and values. Decisions reached through the voting process were also criticized as falling to the lowest common denominator, diluted by concessions to short-term interests that were viewed as detrimental to the lasting protection of Stellwagen Bank (Speaker 4). While one person did express a desire for more "fact-based" decision-making (Speaker 10), research suggests that lack of consensus is not necessarily the result of an information deficit. Instead differing values and beliefs, left unexamined, may undermine a group's ability to reach agreement (Cairns et al. 2014).

Other interviewees who did not focus on a need for information articulated that frustrations with the SAC processes related to communication before, during, and after SAC meetings. One SAC member expressed a desire for better distribution of topics and information prior to the meetings themselves, saying that it was difficult to have 
productive conversations when the SAC is "blindsided" by a question (Speaker 8). While some agenda information is provided prior to SAC meetings, this person felt that more specific information about the types of decisions that would need to be made for any given issue could help prime people for better dialogue (Speaker 8).

To further improve meeting discussions, others felt that greater connection among SAC members would improve their ability to have open discussions and come to decisions. One person mentioned that it would be helpful to know people beyond their position and their official capacity. For example, in the midst of one SAC retreat, some SAC members watched a world series baseball game together after hours. Although the impacts of that single event are hard to assess, this person felt it was a moment that likely had a positive influence on the ability of the group to work together the following day.

Finally, multiple people expressed a desire for better follow-up about decisions and discussions after a SAC meeting takes place. Some interest in this post-meeting follow-up related to past events in which reports and draft documents that were, in part, the result of SAC efforts then disappeared into a "Sanctuary black hole" (Speaker 6). Beyond any specific event, one person felt that some form of simple summary or notice from the Sanctuary about actual outcomes and decisions from SAC discussion (if not finalized during the meeting), as opposed to just meeting notes, would help them better prepare for next steps and feel as though their voices were valued.

Additionally, the role of individual people in the successes and shortcomings of the SAC was discussed as a cross-cutting issue. Sanctuary superintendents were described as each setting a different tone during their tenure for the role of the SAC. One person described past superintendents as taking actions that were, "independent of what 
we [the SAC] said or recommended" (Speaker 13). Although the role of the council as advisory was clearly acknowledged, people articulated that the dismissive nature of past relationships impacted the ability of the SAC to function to its highest potential and the willingness of SAC members to dedicate their time and energy to the process. While not all feedback on past superintendents was negative, multiple people perceived the new superintendent, Pete DeCola, and his actions thus far as a positive change. One person stated, "I think it's refreshing we have Pete who will listen, and we think he will be fair. Because that wasn't the case with the previous superintendent" (Speaker 13).

In addition to those who are directly involved with SAC leadership, some people brought up individual SAC members and expectations for members as having an important influence on the outcomes of SAC meetings. Even preliminary aspects of SAC involvement such as how members are selected to be on the SAC were discussed with one person saying, "we should be prioritizing the community representation that's directly tied to a constituency that's affected over someone who maybe has either more of a pedigree or more to offer the sanctuary, but isn't necessarily tied to the community as closely" (Speaker 8). Concern over the influence of individual actors also carried over to meeting participation. When asked if they thought the SAC functions as it was intended to, one person described some SAC members as focused on their own interests saying, "I don't think most members of the SAC are helping the Sanctuary do their job" (Speaker 4). In this case, the job of a SAC member was viewed as offering expertise and input to further the Sanctuary's mission, as opposed to occupying a seat to protect the interests of a particular sector. 
Reinforcing this, someone else said, "Are they there to serve the Sanctuary or are they there to serve their community, or both?" (Speaker 8). This quote was emblematic of the lack of clarity around the extent to which current members are required to communicate with the groups that they theoretically represent. Although SAC members are required to list ways they will communicate with the groups they represent on their application, one person said, "We really don't supervise or oversee SAC performance...that's why I say so much of the success of the SAC comes down to who's on it" (Speaker 8). While some SAC members did discuss actively sharing information with the groups they represent, communication was limited to immediate co-workers and largely issue-based, meaning fishers may only share fishery related news.

Aside from the details of SAC duties, for those who have been involved with the SAC for many years, attending meetings and enduring the often prolonged decisionmaking process can spark disenchantment with the ability of the SAC and the Sanctuary to effectively manage Stellwagen Bank (Speaker 8). Because SAC members are viewed as a central form of stakeholder participation, cultivating stronger relationships among Sanctuary staff, SAC members, and the communities represented by SAC members could be valuable to ongoing efforts to build support for the Sanctuary's work. SAC members described some recent changes to increase SAC engagement as positive (pre-meeting brainstorming on large easel pads, altered seating patterns), but there was support for expanding on this work.

In discussions with current and former SAC members, there was simultaneous support for greater SAC engagement and acknowledgement that meeting attendance and additional work beyond meetings can be taxing in terms of cost and time. People must 
often take time off of work and in some cases drive hours to reach the meeting. Meeting locations rotate, and mileage may be reimbursed for meeting attendance depending on budgetary restrictions (SBNMS SAC Charter 2018), but the barriers to attendance can be significant, depending on season and a person's occupation. As a result, those who serve on the SAC are a naturally self-selected group of people who can afford to participate. The costs associated with this type of formal participation raise important questions about how well this group of people represents those with an interest in protecting Stellwagen Bank. While many of the critiques and suggestions raised over the course of conversations around the SAC related to dispersing communication around SAC meetings themselves and broadening the scope of intra-SAC communication, there was also interest in broadening public outreach efforts through the Sanctuary as a means of increasing representation and dispersing pressure on the SAC to represent public audiences.

Reflecting on representation through the SAC and other avenues of public outreach will be critical as the Sanctuary begins the management plan review process in 2020 through which some form of public scoping and public comments on draft documents are required. Tangible openings for improvement include communication before, during, and after SAC meetings, as well as clarifying rules and enforcement for communication among SAC members and their constituents. Pre-meeting communication could be strengthened by providing key guiding questions around each topic prior to each meeting to ensure that SAC members have some notion of the specific challenges related to agenda items ahead of time. Additionally, while some governmental members of the SAC or others who have overlap in jobs beyond the SAC may be well acquainted, some 
SAC members may not have relationships that extend beyond knowledge of someone's title or general field. Including small activities to help facilitate communication during SAC meeting breaks or even using small group work during SAC meetings could be beneficial in creating relationships that will then foster better meeting dialogue. Postmeeting follow-up about how the SAC's input was applied an issue and the decision that the Sanctuary made could also be a relatively easy way to ensure that SAC members do not feel ignored or out of the loop on issues they gave their time to consider.

Finally, expectations around SAC performance could be monitored through tools such as yearly check-ins where members report back their methods of communication and who they communicated with through completion of a brief online form (a version of this already exists but could be expanded in detail and in application). Members could also be asked on a rotating basis to provide summaries of their experiences on the SAC or their experiences on Stellwagen Bank in a format that would be suitable for sharing in their own circle as well as through the Sanctuary's channels of communication. All options for extending SAC engagement should consider limitations in time and resources for both members and Sanctuary staff. However, opportunities such as increasing SAC engagement and dispersing effort from the SAC meeting itself to other educational and outreach connections should be explored.

\section{CHAPTER 5: Future Currents}

In interviews and casual conversations, SBNMS was often discussed as an institution in transition. While the Sanctuary still faces complex challenges in balancing multiple uses on Stellwagen Bank, navigating the histories of use, and working to represent many different groups of people who interact with the space, most people were 
hopeful about the Sanctuary's future. One person even said, "I think it's going in a good direction" in reference to continued efforts to increase the Sanctuary's visibility and move away from connotations of the institution as "stealth sanctuary" (Speaker 3). When asked about what they felt should be a priority for the Sanctuary in coming years, support for increased education and outreach was a common theme among participants who are involved in Sanctuary management. One person described their reasoning for this focus by saying, "People right now don't view Stellwagen as a 'place' relative to Monterey" (Harrelson, personal communication, June 2019). Despite this common focus, one person said that they were unsure of what specific issues would rise to the top in the management plan review process and how the Sanctuary would prioritize resources in the coming years.

The most recent Sanctuary Condition Report, released in the spring of 2020, provides some insight into future management priorities through discussion and representation of topics (ONMS 2020). Issues such as climate change, pollution, fishing impacts, and demand for recreation in the Sanctuary, all of which were brought up in interviews along with education and outreach, are prominently addressed. The report also highlights institutional strengths in research stating that the Sanctuary is at the, "forefront of anthropogenic noise and humpback and fin whale research" (ONMS 2020, pg. 16). Qualitative feedback from interviews corroborates this view of the Sanctuary as a leader in expanding knowledge about the resources of Stellwagen Bank.

The Condition Report also acknowledges scarcity of socioeconomic information for many topics such as commercial and recreational fishing, maritime heritage, nonconsumptive recreation, and sense of place, among others. Although education in the 
Sanctuary is rated as "good" with a trend of "improving," the absence of robust social data across activities and groups of people who use Stellwagen Bank may undermine the Sanctuary's education and outreach programming given that understanding target audiences is key to both enterprises (Jacobson et al. 2015, Mahoney and Tang 2016, Mealor and Frost 2012). While MPA management and research has long been driven by a natural science focus (De Santo 2013, Wahle et al. 2003), the lack of social science data is particularly important for sites such as SBNMS that face unique challenges in site access and complicated regional histories that may act as a barrier to support for Sanctuary work.

In contrast with the Condition Report's statement that frames education as a service that, "does not substantially affect the state of natural and cultural resources," (ONMS 2020, pg. 166) many people I spoke with did not distinguish education from other efforts to protect Stellwagen's resources such as potential on the water regulations. When asked about what issues should be a priority for the Sanctuary in the coming years, education and outreach were mentioned by a majority of those interviewed. One person said that education and outreach represent, "the main ability that the sanctuary has to foster conservation" (Speaker 3). This view was paralleled by others who viewed education and outreach as realistic opportunities through which to build support for the Sanctuary's work within groups such as fishers who may be wary of NOAA oversight outside of a more formal participation process (Speaker 5).This suggests that they view education and outreach as central to goals for the Sanctuary's work to protect resources, rather than as peripheral or of lesser importance to protection. 
The work of the current Education Coordinator and the Volunteer Program and SAC Coordinator was generally characterized as successful, and many felt that the Sanctuary's public presence had expanded in recent years. One person said, "the Sanctuary is increasingly successful at getting itself known in the community" (Speaker 4), while another said, "I think it's embracing its role as being very important in communication, two-way communication with all the resource users, and education and outreach" (Speaker 3). However, despite positive reflections on current work, multiple people felt that the Sanctuary should be doing more to develop its regional presence and connect people with the Sanctuary in their backyard.

Funding limitations were acknowledged as an important reality of the Sanctuary's work, and multiple people expressed doubt about the ability of the Sanctuary to expand its staff or programming in the current context (Reeves 2000). However, beyond the simple quantity of outreach programs and efforts, one person questioned the overall direction of outreach at the Sanctuary saying, it's never felt like there's a very coordinated outreach strategy" (Speaker 6). In this context, the Speaker was, in part, questioning what key groups the Sanctuary is attempting to reach. In another casual conversation someone else mentioned that, likely due to funding, the Sanctuary seems opportunistic in its approach with regards to who it targets and how it targets them. Both critiques were a reflection of overarching Sanctuary priorities rather than any individual person or position.

Feedback that supports continued expansion of the Sanctuary's education and outreach programming does not negate the need for on the water protection of cultural and natural resources or research that provides information related to what should be 
protected and how. Instead, this data raises important questions about how the Sanctuary currently frames resource protection and how education may also contribute to long-term resource protection on Stellwagen Bank. While there are obvious differences in the impacts of education and outreach vs. direct regulation of activities such as fishing or the operation of whale watch tours, research by Ardoin et al. (2020) suggests that environmental education can impact the environment through a range of pathways. The relationship between environmental education and environmental action is not linear, and successful programs have common elements of prioritizing local spaces and local needs, including a tangible action-project for participants, and collaborative project development (Ardoin et al. 2020). Additionally, evidence presented by Bicchieri (2016) suggests that relatively constant values, such as protection, can be reframed through altering the "embodiment" (pg. 126) of a particular belief through sharing new information. In other words, although the underlying value of protection for cultural and natural resources may essentially remain the same over time, how people perceive manifestations of that value may be more flexible.

In the context of SBNMS, while the value and importance of natural and cultural resources on Stellwagen Bank is widely acknowledged, how to protect these resources is contested. For some, strong protection and conservation of resources requires on the water protection to restrict activities such as fishing. MPA literature places a heavy emphasis on direct restriction of human activity in marine environments. These methods of protection offer many immediate benefits and should by no means be discounted (Costello and Ballantine 2015, Jones 2014, Lubchenco and Grorud-Colvert 2015). However, MPAs may be incapable of enacting strict on the water protections for a 
number of reasons such as community resistance or lack of funding. In these instances, labeling MPAs as failures due to lack of on the water regulations ignores the potential for these institutions to work towards long-term protection and shifts in social norms through other means such as education and outreach.

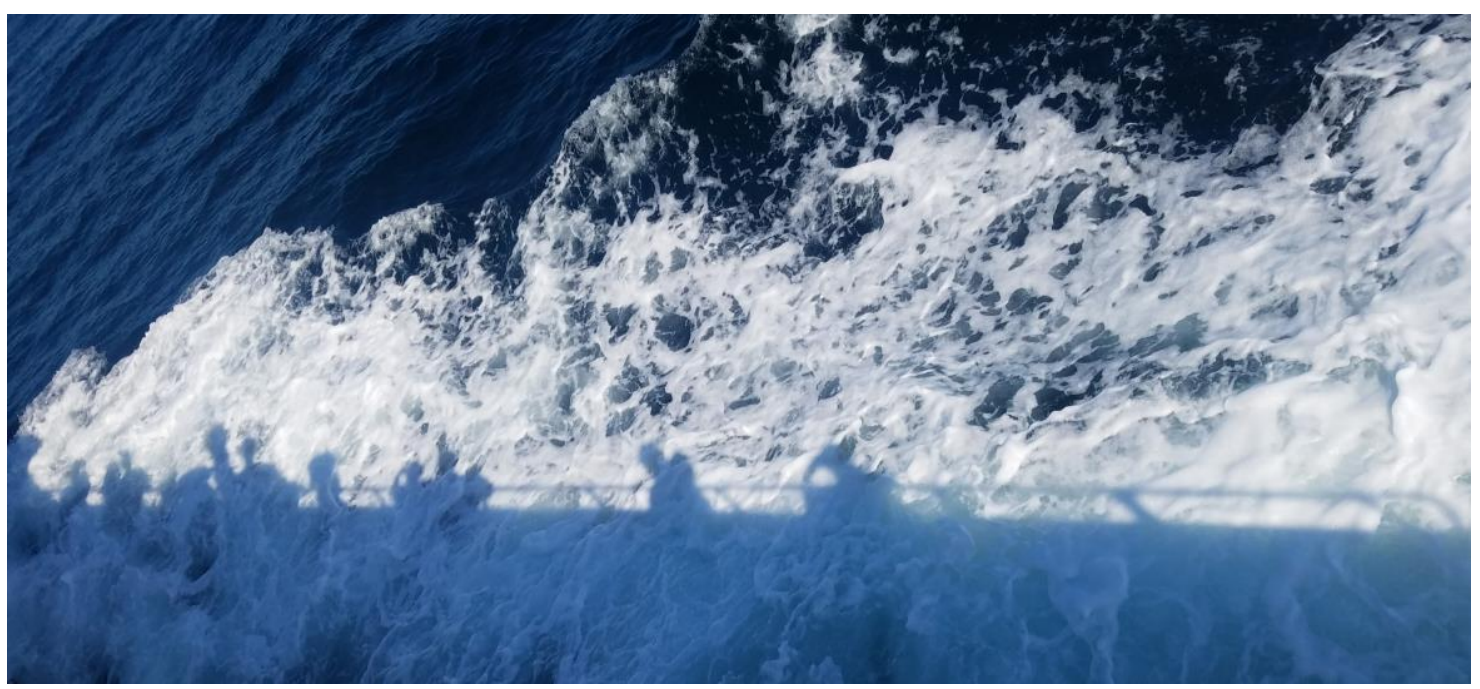

Figure 7. Shadows of whale watch tour passengers on Stellwagen Bank July 2019. Photo by Clea Harrelson.

Additionally, evidence from this exploratory research suggests that the importance of education to interviewees may mean that education could be an alternative embodiment of protection as a result of its potential indirect impacts on the environment. While education and outreach programming may be valuable to the Sanctuary for many reasons, the long-term influence of this work in building relationships between the Sanctuary institution and coastal communities and between coastal communities and ocean resources may factor into the ability of the Sanctuary to enact more stringent protections in the future. Experience on the water and knowledge about Stellwagen Bank were discussed on whale watch tours and in and around the Sanctuary office as key factors in making the Sanctuary important to people whose livelihoods are not directly 
tied to its resources. As one naturalist on a whale watch tour said, "Once they see a whale, they're hooked. They remember it way after they get off the boat."

Articulating education as one form, or alternate embodiment, of long-term protection as opposed to an activity that is beneficial but unrelated to "the state of natural and cultural resources" (ONMS 2020, pg. 166) could be useful in clarifying the ways in which SBNMS does actively protect natural and cultural resources despite few on the water regulations. While the Sanctuary may be limited by federal frameworks and language with regards to how it labels and addresses education and outreach in formal documents such as management plans, this does not preclude efforts to alter any barriers to reframing education and outreach or small local shifts in how these programs are approached. Increased prioritization of education and outreach programming through funding and staff time is one critical, yet unlikely based on interviewee feedback, path to building community presence and relationships. Based on what a few people related to Sanctuary management said, staff simply cannot reach all of the communities they would like to and cannot complete all of the projects they would like to given the current situation (this could be said of any of the Sanctuary's programs, but was described in particular reference to education).

Aside from changes to money and time, the Sanctuary could examine low-cost alternatives such as continued expansion of its social media presence and the cultivation of strategic partnerships with universities and NGOs to help increase its presence in the region. Ultimately, renegotiating the role of education and outreach in protection may help challenge conventional understandings of what constitutes a successful MPA and expand what solutions are viewed as possible to environmental degradation. While some 
people I spoke with expressed dismay and even anger at the expansion and "co-optation" of the term MPA to include spaces that do not have strong on the water protections, reflection on forms of protection that are more attuned to values and beliefs associated with ocean activity may be one, out of many tools, to prevent destruction of marine spaces and build relationships from shore to sea and back again.

\section{Conclusions}

Stellwagen Bank, both the feature and the forms of life it supports, are shaped by a confluence of federal, regional, and local elements. While the general form of the plateau may remain fairly constant, its surface is regularly swept by dredges and storms, and the waters above it are churned by myriad human and non-human marine life. Despite its distance from the buzz of activity on New England's shore and the seemingly placid jostle of the waves on a smooth, calm day, as one person said, Stellwagen Bank and the Sanctuary that now encompasses it, "is not a mythical place where nothing changes" (Speaker 10). In fact, movement and change have been Stellwagen's defining features for thousands of years as it transitioned from a site of dry land that likely supported early coastal peoples to a watery platform that now serves as a focal point for travel, commerce, fishing, tourism, marine life and as a rich cultural landscape.

Management of this ever-changing space is inherently tied to the foundational NMSA of 1972 which marked a turning point in the domestic development of MPAs. Lack of clarity in how to navigate the dual mandate of long-term protection and active use as outlined in the NMSA left Sanctuary staff, SAC members, and people who rely on the Sanctuary to interpret the law for themselves. As a result, goals for the Sanctuary have shifted substantially over the years as individual people and groups prioritize their 
own vision for the space. In many ways this is not unusual. Negotiation about what constitutes an MPA, and in this case, a Sanctuary, will always be in the making as conditions and needs change. However, sustained questions about the extent of SBNMS's authority to provide protection and how it has sought to protect Stellwagen Bank in the past have led to murky understandings of its role in resource management. Although people I spoke with believe that the Sanctuary's visibility has increased in recent years and the institution is producing valuable information about the Bank through research and education, among residents, tourists, and even some people involved in guiding Sanctuary management there is an enduring confusion about what protection through SBNMS can and should be.

In my time on the water and working in the Sanctuary's shoreside communities, comments about the Sanctuary not being a "real" MPA or references to it as an unusual MPA due to the high levels of activity within its boundaries were common. In one instance, after describing my interest in MPA management and my focus on SBNMS, someone chuckled and suggested that I look elsewhere for my research. Questions about protection are frequently framed through analysis of who and what should be protected. Once these elements have been decided, there is an underlying assumption both within conversations about SBNMS and the broader MPA literature that those protections will be applied through regulations that govern on the water activity. While direct action on the water is a logical final step of protection, conceptualizing protection as something that only occurs on the water obscures very real influences of cultural values and coastal politics on marine space. 
Evidence from interviews and conversations with people who are involved or interested in the management of Stellwagen Bank suggests that the Sanctuary's education and outreach programming is central to how people perceive its purpose. As the Sanctuary continues to examine and reevaluate its direction through the 2020 management plan review process, making the ways in which protection takes place on sea and on shore explicit may be a useful foothold in solidifying and articulating its purpose to people who are critical of its limited on the water regulations.

Increasing the number of interviews I conducted and the amount of time I spent on and around Stellwagen Bank may have added greater nuance to perceptions of the Sanctuary's evolution over time. Although the deeper historical context of Stellwagen and the portrayal of fishing history primarily through the lens of white settlers became an important finding, I did not specifically contact or speak with anyone who identified as indigenous to explore ongoing challenges in access and representation in management of marine spaces.

Additionally, my strong focus on meeting with people who have been, or are currently, involved in management as opposed to prioritizing speaking with people who are diverse in terms of race, gender, ability, occupation, culture, and other elements of social identity resulted in a collection of interviews with people who are white and primarily men. This means that my data may not be fully representative of the Sanctuary's social context over time and that my methods, and data are missing key aspects of social identity that may also influence management decisions. My research methodologies and analysis additionally did not extend to the broader systems of management, as I did not include targeted analysis of NOAA as an institution or the 
scientific frameworks that support its work. Ultimately, this project was limited by funding and time.

In terms of future research, expanding insights from people who beyond this narrow subset of people in terms of identity and relation to the Sanctuary would be a useful next step in gauging perceptions of the Sanctuary's goals and actions. Additionally, given the range of purposes and management actions across national marine sanctuaries, research focused on comparing social context across sites could help illuminate how each site works to define protection and what uses are compatible with protection. Ultimately, although the lines on the water that mark SBNMS's boundaries are clearly defined, the complex, interwoven elements of history and politics that are presented within this brief exploration of the Sanctuary's relationships and social context are less clear. More social science research is necessary to help make visible the ways in which SBNMS navigates management decisions given its multiscale social context and how the space now called Stellwagen Bank came to be. 
"Do not follow

where the path may lead.

Go, instead,

where there is no path

and leave a trail.”

\section{Ralph Waldo Emerson}

*Quote included on the inside, back cover of the SBNMS's Final Management Plan and Environmental Assessment (ONMS 2010). 


\section{APPENDIX A}

Sample Interview Questions:

1. Demographics:
a. What is your age?
b. How would you describe your gender?
c. How would you describe your racial and/or ethnic identity?
d. In what town is your primary residence? Your primary port (if applicable)?
e. Can you tell me about your career history?

2. What is Stellwagen Bank?
a. What does Stellwagen Bank mean to you?
b. How long have you been visiting Stellwagen Bank?
c. How did you, or others you know, use Stellwagen Bank in the past?
d. How has Stellwagen Bank changed over your lifetime?
e. How do you use Stellwagen Bank now?
f. Do you rely on Stellwagen Bank for your livelihood?

3. What is a national marine sanctuary?
a. How would you describe your role within Stellwagen Bank National Marine Sanctuary?
b. How long have you been involved with/used the sanctuary?

4. What is the purpose of Stellwagen Bank National Marine Sanctuary?
a. Why was SBNMS designated?
b. What is the purpose of SBNMS now?
c. What other roles/uses occur in the sanctuary that impact you? 
d. In sanctuary documents, SBNMS is described as a space managed for multiple uses. How well do these uses coexist? Is there conflict?

5. Who was involved in helping get Stellwagen designated?

6. Who is involved in making policy for the sanctuary?

a. How have different groups involved in management changed since designation?

b. Are there people who aren't involved in making policy that should be?

c. How much influence do you (or a group you belong to) have over policy decisions at the sanctuary?

d. How would you describe your relationship with people who manage the sanctuary/with people who use the sanctuaries resources?

7. Is Stellwagen Bank National Marine Sanctuary successful?

a. As a national marine sanctuary? As a multi-use zone?

8. Who benefits from Stellwagen Bank National Marine Sanctuary?

9. Who is harmed by the existence of Stellwagen Bank National Marine Sanctuary?

10. How have the goals of Stellwagen Bank National Marine Sanctuary changed since its designation?

a. What do you see as milestones in how management has changed?

11. How would describe the direction of management at the sanctuary now?

12. What do you think should be a priority in the upcoming sanctuary management plan review process? 


\section{BIBLIOGRAPHY}

Adams, W. M., \& Mulligan, M. (Eds.). 2003. Decolonizing nature: strategies for conservation in a post-colonial era. Earthscan.

Agardy, T., Bridgewater, P., Crosby, M.P., Day, J., Dayton, P.K., Kenchington, R., Laffoley, D., McConney, P., Murray, P.A., Parks, J.E. and Peau, L. 2003. Dangerous targets? Unresolved issues and ideological clashes around marine protected areas. Aquatic conservation: marine and freshwater ecosystems, 13(4), pp.353-367.

Agardy, T., Di Sciara, G. N., \& Christie, P. 2011. Mind the gap: addressing the shortcomings of marine protected areas through large scale marine spatial planning. Marine Policy, 35(2), 226-232.

Ardoin, N. M., Bowers, A. W., \& Gaillard, E. 2020. Environmental education outcomes for conservation: A systematic review. Biological Conservation, 241, 108224.

Battista, T., Clark, R., \& Pittman, S. 2006. An ecological characterization of the Stellwagen Bank National Marine Sanctuary Region: oceanographic, biogeographic, and contaminants assessment. Silver Spring, MD, NOAA/National Ocean Service , 356pp. (NOAA Technical Memorandum NOS NCCOS, 45). Accessed 3 March 2020 from http://aquaticcommons.org/14584/.

Basta, D. 2005. Availability of Seats for the Stellwagen Bank National Marine Sanctuary Advisory Council: A Notice by the National Oceanic and Atmospheric Administration. Document citation: 70 FR 11194. Accessed 3 January 2020 from https://www.federalregister.gov/d/05-4392.

Baur, D., Lindley, T., Murphy, A., Hampton, P., Smyth, P., Higgs, S., ... \& Hupp, M. 2013. Area---Based Management of Marine Resources: A Comparative Analysis of the National Marine Sanctuaries Act and Other Federal and State Legal Authorities. Perkins Coie LLP, Washington, DC.

Bell, E. L. 2009. Cultural resources on the New England coast and continental shelf: research, regulatory, and ethical considerations from a Massachusetts perspective. Coastal Management, 37(1), 17-53.

Berghöfer, A., Wittmer, H. and Rauschmayer, F. 2008. Stakeholder participation in ecosystem-based approaches to fisheries management: A synthesis from European research projects. Marine Policy, 32(2), pp.243-253. 
Bernard, H. R. 2017. Research methods in anthropology: Qualitative and quantitative approaches. Rowman \& Littlefield.

Bernstein, D. J. 2006. Long-term continuity in the archaeological record from the coast of New York and southern New England, USA. Journal of Island \& Coastal Archaeology, 1(2), 271-284.

Beverton, R. J. H., \& Holt, S. J. 1957. On the dynamics of exploited fish populations. Fisheries Investigations Series II. Marine Fisheries, Great Britain Ministry of Agriculture, Fisheries and Food, 19.

Bicchieri, C. 2016. Norms in the wild: How to diagnose, measure, and change social norms. Oxford University Press.

Bigford, T. Stellwagen Bank NMS. June 11, 1991. Fax communication. Accessed June 2019 from physical copies at Stellwagen Bank National Marine Sanctuary main office in Scituate, MA.

Stellwagen Sanctuary. April 5, 1993. Fax communication. Accessed June 2019 from physical copies at Stellwagen Bank National Marine Sanctuary main office in Scituate, MA.

Bohnsack, J.A., Ault, J. S., Causey, B. 2004. Why have no-take marine protected areas? In American Fisheries Society Symposium (Vol. 42, pp. 185-193).

Bolster, W. J. 2006. Opportunities in Marine Environmental History, Environmental History 11: 567-97.

Borrelli, P. 2009. Stellwagen: The Making and Unmaking of a National Marine Sanctuary. University Press of New England.

Bowen, G.A. 2009. Document analysis as a qualitative research method. Qualitative research journal, 9(2), pp.27-40.

Brax, J. 2002. Zoning the oceans: using the National Marine Sanctuaries Act and the Antiquities Act to establish marine protection areas and marine reserves in America. Ecology law quarterly, 29(1), 71-129.

Brody, S. D. 1998. An evaluation of the establishment processes for Marine Protected Areas in the Gulf of Maine: Understanding the role of community involvement and public participation. Gulf of Maine Council on the Marine Environment, Report, (3). 
Bruchac, M., Hart, S., \& Wobst, H. M. (Eds.). 2016. Indigenous archaeologies: a reader on decolonization. Routledge.

Caveen, A., Polunin, N., Gray, T. and Stead, S.M. 2014. The controversy over marine protected areas: science meets policy. Springer.

Cairns, R., Sallu, S. M., \& Goodman, S. 2014. Questioning calls to consensus in conservation: a Q study of conservation discourses on Galápagos. Environmental Conservation, 41(1), 13-26.

Chaffee, J. March 10, 1992. "Planned marine sanctuary 'good news for the whales"'. The Patriot Ledger.

Chandler, W. J. 2006. The Future of the National Marine Sanctuaries Act in the TwentyFirst Century. Marine Conservation Institute: The National Marine Sanctuaries Act.

Accessed 1 January 2020 from https://marineconservation.org/media/filer_private/2011/04/18/chandler_2006.pdf.

Chandler, W.J. and Gillelan, H. 2007. How the National Marine Sanctuaries Act diverged from the Wilderness Act model and lost its way in the land of multiple use. In: Watson, Alan; Sproull, Janet; Dean, Liese, comps. Science and stewardship to protect and sustain wilderness values: Eighth World Wilderness Congress symposium; September 30October 6, 2005; Anchorage, AK. Proceedings RMRS-P-49. Fort Collins, CO: US Department of Agriculture, Forest Service, Rocky Mountain Research Station. (49), p. 573-578.

Charmaz, K. and Belgrave, L. 2012. Qualitative interviewing and grounded theory analysis. The SAGE handbook of interview research: The complexity of the craft, 2, pp. 347-365.

Christie, P. 2004. Marine protected areas as biological successes and social failures in Southeast Asia. In American fisheries society symposium, 42, pp. 155-164.

Costello, M. J., \& Ballantine, B. 2015. Biodiversity conservation should focus on no-take Marine Reserves: 94\% of Marine Protected Areas allow fishing. Trends in ecology \& evolution, 30(9), 507-509.

Cowan Jr, J. H., Rice, J. C., Walters, C. J., Hilborn, R., Essington, T. E., Day Jr, J. W., \& Boswell, K. M. 2012. Challenges for implementing an ecosystem approach to fisheries management. Marine and Coastal Fisheries, 4(1), 496-510. 
Creswell, J.W., Plano Clark, V.L., Gutmann, M.L. and Hanson, W.E. 2003. Advanced mixed methods research designs. Handbook of mixed methods in social and behavioral research, 209, p.240.

Crutchfield, L. R. 2018. How Change Happens: Why Some Social Movements Succeed While Others Don't. John Wiley \& Sons.

Dalton, T.M. 2005. Beyond biogeography: a framework for involving the public in planning of US marine protected areas. Conservation Biology, 19(5), pp.1392-1401.

Dare, M., Schirmer, J., \& Vanclay, F. 2014. Community engagement and social licence to operate. Impact Assessment and Project Appraisal, 32(3), 188-197.

Dell'Apa, A., Fullerton, A., Schwing, F. and Brady, M.M. 2015. The status of marine and coastal ecosystem-based management among the network of US federal programs. Marine Policy, 60, pp.249-258.

De Santo, E. M. 2013. Missing marine protected area (MPA) targets: how the push for quantity over quality undermines sustainability and social justice. Journal of environmental management, 124, 137-146.

Dedication Ceremony: Preliminary Program. 1993. Stellwagen Bank National Marine Sanctuary. Plymouth, MA. Accessed June 2019 from physical copies at Stellwagen Bank National Marine Sanctuary main office in Scituate, MA.

Douvere, F. 2008. The importance of marine spatial planning in advancing ecosystembased sea use management. Marine policy, 32(5), pp.762-771.

Dudley, N. (Ed.) 2008. Guidelines for Applying Protected Area Management Categories. Gland, Switzerland: IUCN. x + 86pp. WITH Stolton, S., P. Shadie and N. Dudley (2013). IUCN WCPA Best Practice Guidance on Recognising Protected Areas and Assigning Management Categories and Governance Types, Best Practice Protected Area Guidelines Series No. 21, Gland, Switzerland: IUCN.

Dumanoski, D. 1992. From Cape Cod to N.H., Stellwagen Bank will become sanctuary rich in marine life. Providence Journal (RI), pp. A-01. Available from NewsBank: Access World News - Historical and Current: https://infoweb-newsbankcom.uri.idm.oclc.org/apps/news/documentview?p=WORLDNEWS\&docref=news/1525111641E9AB78.

Ehler, R. 2011. Economic Impact Analysis of the Stellwagen Bank National Marine Sanctuary Proposed Sanctuary Ecological Research Area. Office of National Marine Sanctuaries, NOAA, Silver Spring, MD. 
Farady, S. E. 2006. Compatible use within national marine sanctuaries: determining meaningful implementation. Ocean \& Coastal LJ, 12, 1.

Fox, H. E., Mascia, M. B., Basurto, X., Costa, A., Glew, L., Heinemann, D., ... \& Recchia, C. A. 2012. Reexamining the science of marine protected areas: linking knowledge to action. Conservation Letters, 5(1), 1-10.

Gell, F.R. and Roberts, C.M. 2003. Benefits beyond boundaries: the fishery effects of marine reserves. Trends in Ecology \& Evolution, 18(9), pp.448-455.

Gibson, R. N., Atkinson, R. J. A., \& Gordon, J. D. M. 2010. Historical reconstruction of human-induced changes in US estuaries. Oceanography and marine biology: an annual review, 48, 267-338.

Gill, D. A., Mascia, M. B., Ahmadia, G. N., Glew, L., Lester, S. E., Barnes, M., ... \& Holst, S. 2017. Capacity shortfalls hinder the performance of marine protected areas globally. Nature, 543(7647), 665-669.

Gillian, G. 2019. "Researchers exploring wreck of SS Portland. Here's how to watch." Portland Press Herald. Accessed 2 February 2020 from https://www.pressherald.com/2019/09/17/researchers-are-exploring-the-ss-portlandshipwreck-heres-how-to-watch/.

Gloucester Fisherman's Memorial. n.d. National Park Service, National Register of $\begin{array}{llllll}\text { Historic Places. } & \text { Accessed } & 2020 & \text { January }\end{array}$ https://www.nps.gov/nr/travel/maritime/glo.htm.

Gray, N.J. 2010. Sea change: exploring the international effort to promote marine protected areas. Conservation and Society, 8(4), p.331.

Greater Atlantic Regional Fisheries Office (GARFO). 2018. Greater Atlantic Regional Bulletin: Atlantic Sea Scallop Fishery; Historic Shipwreck Avoidance on Stellwagen Bank. NOAA Fisheries. National Oceanic and Atmospheric Administration. Accessed 18 April 2019 from https://www.greateratlantic.fisheries.noaa.gov/nr/2018/March/18scalngomfw29stellwage nshipwrecksitesphl.pdf.

Guénette, S., Lauck, T. and Clark, C. 1998. Marine reserves: from Beverton and Holt to the present. Reviews in fish biology and fisheries, 8(3), pp.251-272.

Hall, L. K. 2008. Strategies of erasure: US colonialism and native Hawaiian feminism. American Quarterly, 60(2), 273-280. 
Halpern, B. S., Lester, S. E., \& McLeod, K. L. 2010. Placing marine protected areas onto the ecosystem-based management seascape. Proceedings of the National Academy of Sciences, 107(43), 18312-18317.

Hargreaves-Allen, V., Mourato, S., \& Milner-Gulland, E. J. 2011. A global evaluation of coral reef management performance: are MPAs producing conservation and socioeconomic improvements? Environmental management, 47(4), 684-700.

Hilborn, R. 2015. Marine protected areas miss the boat. Science, 350(6266), 1326-1326.

Hoagland, P. and A.E. Meeks. 2000. The demand for whale watching at Stellwagen Bank National Marine Sanctuary. In: The economic contribution of whale watching to regional economies: Perspectives from two national marine sanctuaries. Marine Sanctuaries Conservation Series MSD-00-2. U.S. Department of Commerce, National Oceanic and Atmospheric Administration, Marine Sanctuaries Division, Silver Spring, MD.

Inniss, L., Simcock, A., Ajawin, A.Y., Alcala, A.C., Bernal, P., Calumpong, H.P., Araghi, P.E., Green, S.O., Harris, P. and Kamara, O.K. 2017. The first global integrated marine assessment: world ocean assessment. United Nations General Assembly. United Nations.

International Union for Conservation of Nature (IUCN). 2020. Protected Areas: Protected Area Categories. Retrieved 12 December 2020 from https://www.iucn.org/theme/protected-areas/about/protected-area-categories.

Jackson J. B. C., M. X. Kirby, W. H. Berger, K. A. Bjorndal, L. W. Botsford, B.J. Bourque, R. H. Bradbury, R. Cooke, J. Erlandson, J. A. Estes, T. P. Hughes, S. Kidwell, C. B. lange, H. S. Lenihan, J. M. Pandolfi, C. H. Peterson, R. S Steneck, M. J. Tegner \& R. R. Warner. 2001. Historical overfishing and the recent collapse of coastal ecosystems. Science 293, pp 629-638.

Jacobson, S. K., McDuff, M. D., \& Monroe, M. C. 2015. Conservation education and outreach techniques. Oxford University Press.

Johannes, R.E. 1978. Traditional marine conservation methods in Oceania and their demise. Annual Review of Ecology and Systematics, 9(1), pp.349-364.

1998. The case for data-less marine resource management: examples from tropical nearshore finfisheries. Trends in Ecology \& Evolution, 13(6), pp.243-246.

Jones, P. J. 2014. Governing marine protected areas: resilience through diversity. Routledge. 
Kaza, S. 1988. Community involvement in marine protected areas. Oceanus 31(1): 7581.

Lawrence, M., Marx, D., Galluzzo, J. 2015. Shipwrecks of Stellwagen Bank: Disaster in New England's National Marine Sanctuary. The History Press, Charleston, SC.

Lubchenco, J., \& Grorud-Colvert, K. 2015. Making waves: The science and politics of ocean protection. Science, 350(6259), 382-383.

Luo, L. and Wildemuth, B.M. 2009. Semistructured interviews. In Applications of social research methods to questions in information and library science, pp.222-231. Libraries Unlimited.

Mahajan, S.L. and Daw, T. 2016. Perceptions of ecosystem services and benefits to human well-being from community-based marine protected areas in Kenya. Marine Policy, 74, pp.108-119.

Mahoney, L. M., and Tang, T. 2016. Strategic social media: From marketing to social change. John Wiley \& Sons.

Marx, D., and Lawrence, M. 2006. Nomination of Frank A. Palmer and Louise B. CraryShipwreck Remains to the National Register of Historic Places." National Register of Historic Places Registration Form. Scituate, MA: Stellwagen Bank National Marine Sanctuary.

Mascia, M. B., and Claus, C. A. 2009. A property rights approach to understanding human displacement from protected areas: the case of marine protected areas. Conservation Biology, 23(1), 16-23.

Mather, R., and Jensen, J. 2010. Investigations into Block Island's Submerged Cultural Sites and Landscapes for the Rhode Island Ocean Special Area Management Plan 2010. Rhode Island Ocean Special Area Management Plan, Technical Report \#5. Rhode Island Coastal Resources Management Council. Accessed 1 March 2020 from http://www.crmc.ri.gov/samp_ocean/finalapproved/TechRep05-Mather-Jensen-CulturalResources.pdf.

McDonald, S. L., \& Gallagher, D. R. 2015. A story about people and porpoises: consensus-based decision making in the shadow of political action. Environmental management, 56(4), 814-821. 
McKenzie, M. 2018. Breaking the Banks: Representation and Realities in the New England Fisheries, 1866-1966. Environmental History of the Northeast Series, University of Massachusetts Press.

Mealor, R., \& Frost, R. 2012. Innovative outreach methods for adult education in the 21st century: knowing your audience and moving from the centerpiece to the sideline.

Rangelands, 34(3), 41-44.

Merwin, D. E., Lynch, D. P., \& Robinson, D. S. 2003. Submerged prehistoric sites in southern New England: Past research and future directions. Bulletin of the Archaeological Society of Connecticut, 65, 41-56. https://connarchaeology.org/ASC65.pdf\#page=39.

Moore, A. February 2018. Participant Observation Workshop Materials.

Morin, T. 2001. Sanctuary advisory councils: involving the public in the National Marine Sanctuary Program. Coastal Management, 29(4), 327-339.

Mrozowski, S. A. 1994. The discovery of a Native American cornfield on Cape Cod. Archaeology of Eastern North America, 47-62.

Murawski, S. A., Wigley, S. E., Fogarty, M. J., Rago, P. J., \& Mountain, D. G. (2005). Effort distribution and catch patterns adjacent to temperate MPAs. ICES Journal of Marine Science, 62(6), 1150-1167.

National Center for Ecological Analysis and Synthesis (NCEAS). 2001. Scientific consensus statement on marine reserves and marine protected areas. Annual Meeting of the American Association for the Advancement of the Sciences. Accessed 18 December 2019 from https://www.nceas.ucsb.edu/consensus/consensus.pdf.

National Marine Sanctuaries Act (NMSA), 16 U.S.C. $§ ~ 1431-1445 c . ~ 2000$. Accessed 4 January 2020 from https://nmssanctuaries.blob.core.windows.net/sanctuaries$\mathrm{prod} / \mathrm{media} /$ archive/library/national/nmsa.pdf.

National Oceanic and Atmospheric Administration (NOAA). 2020. Legislation: The National Marine Sanctuaries Act. National Ocean Service. Accessed 1 January 2020 from https://sanctuaries.noaa.gov/about/legislation/.

National Research Council. 2001. Historical Background and Evaluation of Marine Protected Areas in the United Sates. Marine Protected Areas: Tools for Sustaining Ocean 
Ecosystems. Washington, DC: The National Academies Press. Accessed 2 April 2019 from https://www.nap.edu/read/9994/chapter/10.

Native Land Digital. 2018. Native Land Map. Accessed 2 January 2020 from https://native-land.ca/.

Ocean Sanctuaries Act. 2011. Massachusetts Office of Coastal Zone Management Policy Guide: Ocean Sanctuaries Act. Massachusetts Office of Coastal Zone Management, pg. 16. Accessed 3 April 2020 from https://www.mass.gov/files/documents/2016/08/qc/czmpolicy-guide-october2011.pdf.

Office of National Marine Sanctuaries (ONMS). 2010. Stellwagen Bank National Marine Sanctuary Final Management Plan and Environmental Assessment. U.S. National Oceanic and Atmospheric Administration. Department of Commerce. Silver Spring, MD. Accessed 1 April 2019 from https://nmsstellwagen.blob.core.windows.net/stellwagen$\mathrm{prod} / \mathrm{media} /$ archive/management/fmp/pdfs/sbnms_fmp2010_lo.pdf.

2020. Condition Report: Findings of Status and Trends for 2007-2018. U.S. Department of Commerce, National Oceanic and Atmospheric Administration, Office of National Marine Sanctuaries, Silver Spring, MD. 263 pp.

Orr, R., Sharratt, K., \& Iqbal, M. 2019. American Indian erasure and the logic of elimination: an experimental study of depiction and support for resources and rights for tribes. Journal of Ethnic and Migration Studies, 45(11), 2078-2099.

Owen, D. 2002. The Disappointing History of the National Marine Sanctuaries Act. NYU Envtl LJ, 11, p.711.

Peterson, M. N., Peterson, M. J., \& Peterson, T. R. 2005. Conservation and the myth of consensus. Conservation biology, 19(3), 762-767.

Pollnac, R. B., \& Pomeroy, R. S. 2005. Factors influencing the sustainability of integrated coastal management projects in the Philippines and Indonesia. Ocean \& coastal management, 48(3-6), 233-251.

Pomeroy, R. S., Mascia, M. B., \& Pollnac, R. B. 2007. Marine protected areas: the social dimension. FAO fisheries report, (825), 149-81.

Pomeroy, R. S., Parks, J. E., \& Watson, L. M. 2004. How is your MPA doing? A guidebook of natural and social indicators for evaluating marine protected area management effectiveness. IUCN, Gland, Switzerland and Cambridge, UK. 
Reed, M. S. 2008. Stakeholder participation for environmental management: a literature review. Biological conservation, 141(10), 2417-2431.

Reeves, R. R. 2000. The value of sanctuaries, parks, and reserves (protected areas) as tools for conserving marine mammals (p. 50). Bethesda, MD: Marine Mammal Commission.

Rhode Island Coastal Resources Management Council (RI CRMC). 2010. Rhode Island Ocean Special Area Management Plan: Volume 1. Accessed 3 March from http://www.crmc.ri.gov/samp_ocean/finalapproved/RI_Ocean_SAMP.pdf.

Roberts, C. (2012). Ocean of life. Penguin UK.

Rock, J., Sima, E., \& Knapen, M. 2019. What is the ocean: A sea-change in our perceptions and values? Aquatic Conservation: Marine and Freshwater Ecosystems. Accessed 2 January 2020 from https://onlinelibrary.wiley.com/doi/full/10.1002/aqc.3257?casa_token=dIe3XCqy2QAAAAA\%3Au2vSdTzhjT1KdyRw01lHqQaNz6HquNkCj3DDxDbHyS35TJ2PhcyL08Bk2jgiDbn5DjTmni3q0qA_eP7.

Sala, E., \& Giakoumi, S. 2018. No-take marine reserves are the most effective protected areas in the ocean. ICES Journal of Marine Science, 75(3), 1166-1168.

Sala, E., Lubchenco, J., Grorud-Colvert, K., Novelli, C., Roberts, C. and Sumaila, U.R. 2018. Assessing real progress towards effective ocean protection. Marine Policy, 91, pp.11-13.

Sanctuaries and Reserves Division. 1993. Stellwagen Bank National Marine Sanctuary Final Environmental Impact Statement/Management Plan, Volume 1. Washington, D.C.: U.S. Department of Commerce, National Oceanic Atmospheric Administration, Sanctuaries and Reserves Division.

Sarri, K. 2018. Celebrating 46 Years of the National Marine Sanctuaries Act. National Marine Sanctuaries Foundation. Accessed 14 April 2019 from https://marinesanctuary.org/blog/celebrating-46-years-of-the-national-marinesanctuaries-act/?gclid=CjwKCAjwkcblBRB_EiwAFmfyySpKe7Xm2nMaLctFnZD3sCUUt_DPPxqRyTfFN9fIr8Xz0ikgC_dyRoC5MQAvD_BwE. 
Scheiber, H. N. 1998. The Stratton Commission: An Historical Perspective on Policy Studies in Ocean Governance, 1969 and 1998. The Stratton Roundtable, Washington, $D C$.

Silliman, S. W. 2009. Change and continuity, practice and memory: Native American persistence in colonial New England. American antiquity, 74(2), 211-230.

Singleton, S. 2009. Native people and planning for marine protected areas: how "stakeholder" processes fail to address conflicts in complex, real-world environments. Coastal Management, 37(5), 421-440.

Smith, L. T. 2013. Decolonizing methodologies: Research and indigenous peoples. Zed Books Ltd.

Stellwagen Bank National Marine Sanctuary (SBNMS) Sanctuary Advisory Council (SAC) Charter. 2018. Accessed 2 January 2020 from https://nmsstellwagen.blob.core.windows.net/stellwagen-prod/media/docs/20180716advisory-council-charter.pdf.

Sutherland, L. 2008. An Analysis of Habitat Conservation in National Marine Sanctuaries: A Case Study of the Channel Islands, Flower Garden Banks, and Stellwagen Bank National Marine Sanctuaries. Accessed 3 January 2020 from https://dukespace.lib.duke.edu/dspace/bitstream/handle/10161/480/MP_lk?sequence=1.

Telegram \& Gazette. New England gets marine sanctuary / / stellwagen bank preserve dedicated: [ALL edition]. (June 27, 1993). Telegram \& Gazette. Accessed 3 January from http://uri.idm.oclc.org/login?url=https://search-proquestcom.uri.idm.oclc.org/docview/268487421 ?accountid=28991.

Terrell, B.G. 1994. Fathoming our past: historical contexts of the National Marine Sanctuaries. National Marine Sanctuaries Program. National Oceanic and Atmospheric $\begin{array}{llllll}\text { Administration. } & \text { Accessed } & 1 & \text { April } & 2019 & \text { from }\end{array}$ https://nmssanctuaries.blob.core.windows.net/sanctuaries$\mathrm{prod} / \mathrm{media} /$ archive/library/pdfs/fop.pdf.

Voyer, M., Dreher, T., Gladstone, W., \& Goodall, H. 2013. Who cares wins: The role of local news and news sources in influencing community responses to marine protected areas. Ocean \& coastal management, 85, 29-38.

Wahle, C., Lyons S., Barba, K., Bunce, L., Fricke, P., Nicholson, E., Orbach, M., Pomeroy, C., Recksiek, H. and Uravitch, J. 2003. Social Science Research Strategy for 
Marine Protected Areas. National Marine Protected Areas Center Science Institute.

Accessed 2 January 2020 from

http://www.mpa.gov/virtual_library/Publications/ssr_strategy.pdf.

Waller Jr, J. N. 2000. Late Woodland settlement subsistence in southern New England revisited: The evidence from coastal Rhode Island. North American Archaeologist, 21(2), 139-153.

Warrior, R. 2018. Speaking of Indigenous Politics: Conversations with Activists, Scholars, and Tribal Leaders. University of Minnesota Press.

Weber, M. 1988. Marine sanctuaries: a forgotten cause? Defenders May/June:16-23. 1997. Are National Marine Sanctuaries protecting marine wildlife? Can they? Unpubl. report submitted to the Center for Marine Conservation, Washington, D.C. $44 \mathrm{pp}$.

Whale SENSE. 2020. Whale SENSE Atlantic Requirements. Accessed 1 January 2020 from https://whalesense.org/resources/atlantic/whale-sense-requirements/.

Wiener, C.S., Needham, M.D. and Wilkinson, P.F. 2009. Hawaii's real-life marine park: interpretation and impacts of commercial marine tourism in the Hawaiian Islands. Current Issues in Tourism, 12(5-6), pp.489-504. 